\title{
Passive Safety Features Evaluation of KIPT Neutron Source Facility
}

Nuclear Engineering Division 


\title{
About Argonne National Laboratory
}

Argonne is a U.S. Department of Energy laboratory managed by UChicago Argonne, LLC under contract DE-AC02-06CH11357. The Laboratory's main facility is outside Chicago, at 9700 South Cass Avenue, Argonne, Illinois 60439. For information about Argonne

and its pioneering science and technology programs, see www.anl.gov.

\section{DOCUMENT AVAILABILITY}

Online Access: U.S. Department of Energy (DOE) reports produced after 1991 and a growing number of pre-1991 documents are available free via DOE's SciTech

Connect (http://www.osti.gov/scitech/)

\author{
Reports not in digital format may be purchased by the public from \\ the National Technical Information Service (NTIS): \\ U.S. Department of Commerce \\ National Technical Information \\ Service 5301 Shawnee Rd \\ Alexandria, VA 22312 \\ www.ntis.gov \\ Phone: (800) 553-NTIS (6847) or (703) 605-6000 \\ Fax: (703) 605-6900 \\ Email: orders@ntis.gov
}

\author{
Reports not in digital format are available to DOE and DOE contractors from \\ the Office of Scientific and Technical Information (OSTI): \\ U.S. Department of Energy \\ Office of Scientific and Technical Information \\ P.O. Box 62 \\ Oak Ridge, TN 37831-0062 \\ www.osti.gov \\ Phone: (865) 576-8401 \\ Fax: (865) 576-5728 \\ Email: reports@osti.gov
}

\begin{abstract}
Disclaimer
This report was prepared as an account of work sponsored by an agency of the United States Government. Neither the United States Government nor any agency thereof, nor UChicago Argonne, LLC, nor any of their employees or officers, makes any warranty, express or implied, or assumes any legal liability or responsibility for the accuracy, completeness, or usefulness of any information, apparatus, product, or process disclosed, or represents that its use would not infringe privately owned rights. Reference herein to any specific commercial product, process, or service by trade name, trademark, manufacturer, or otherwise, does not necessarily constitute or imply its endorsement, recommendation, or favoring by the United States Government or any agency thereof. The views and opinions of document authors expressed herein do not necessarily state or reflect those of the United States Government or any agency thereof, Argonne National Laboratory, or UChicago Argonne, LLC.
\end{abstract}


ANL-16/15

\section{Passive Safety Features Evaluation of KIPT Neutron Source Facility}

By

Zhaopeng Zhong and Yousry Gohar

Nuclear Engineering Division, Argonne National Laboratory

June 2016 
(This Page Intentionally left blank) 


\section{$\underline{\text { Table of Contents }}$}

$\underline{\text { Page }}$

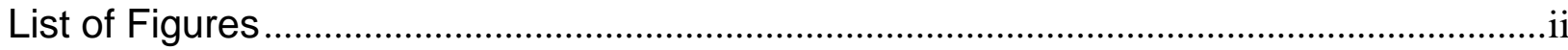

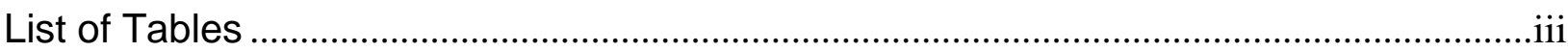

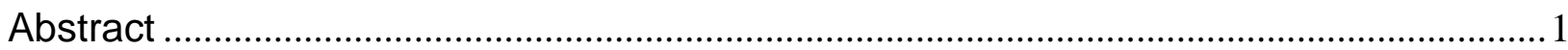

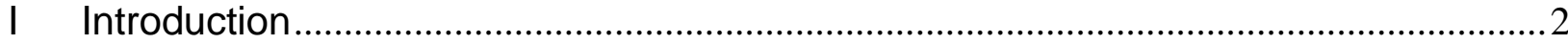

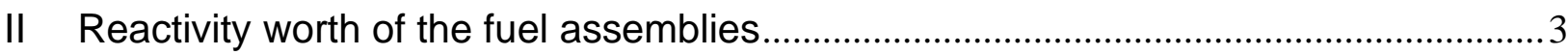

III Subcritical assembly reactivity feedback due to the change in the temperature and

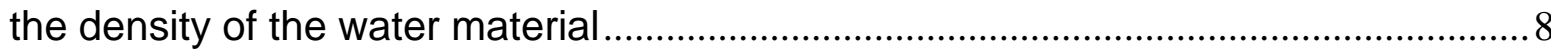

IV Subcritical assembly reactivity feedback due to the change in the fuel material

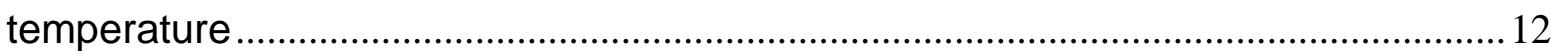

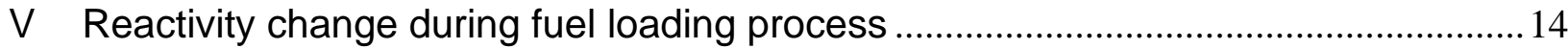

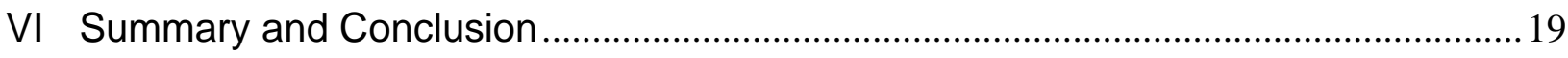

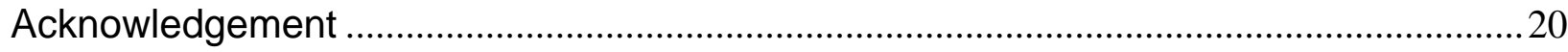

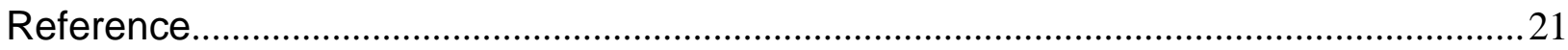




\section{List of Figures}

\section{Page}

Figure 1 Radial configuration of the subcritical assembly, with reflector and water tank

Figure 2 Radial Configuration of KIPT core using tungsten target, with different number of FAs loaded..

Figure 3 Radial Configuration of KIPT core using uranium target, with different number of FAs loaded.

Figure 4 K-eff vrs number of FAs loaded, using tungsten target ..............................

Figure 5 K-eff vrs number of FAs loaded, using uranium target.............................. 7

Figure 6 Core configurations of KIPT neutron source facility, with k-eff just above

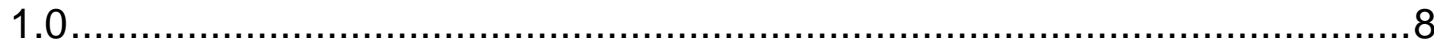

Figure 7 Radial configurations of KIPT core at the beginning of fuel loading process, with only beryllium and dummy assemblies loaded

Figure 8 k-eff curve during the initial loading process, for tungsten and uranium target cases

Figure 9 Core configurations of KIPT core, during the process of loading the last FA, for tungsten target case.

Figure 10 Core configurations of KIPT core, during the process of loading the last $\mathrm{FA}$, for uranium target case

Figure 11 Core configurations of KIPT core, for tungsten target case with 38 FAs loaded, with beryllium assembly replaced by dummy assembly

Figure 12 Core configurations of KIPT core, for tungsten target case with 38 FAs loaded, with beryllium assembly replaced by water hole

Figure 13 Core configurations of KIPT core, for uranium target case with 37 FAs loaded, with beryllium assembly replaced by dummy assembly

Figure 14 Core configurations of KIPT core, for uranium target case with 37 FAs loaded, with beryllium assembly replaced by water hole 


\section{List of Tables}

Page

Table 1. Water density at different temperature

9

Table 2. $k_{\text {eff }}$ values as a function of the water temperature of the target assembly and the fuel region for the reference subcritical assemblies with extra fuel assemblies

Table 3. $\mathrm{k}_{\text {eff }}$ values as a function of the water temperature of the fuel region for the reference subcritical assemblies with extra fuel assemblies

Table 4. $k_{\text {eff }}$ values as a function of the water temperature of the target assembly and the fuel region for the reference subcritical assemblies.

Table 5. $k_{\text {eff }}$ values as a function of the water temperature of the fuel region for the reference subcritical assemblies.

Table $6 . k_{\text {eff }}$ values as a function of the fuel temperature for the reference subcritical assemblies with extra fuel assemblies

Table 7. $k_{\text {eff }}$ values as a function of the fuel temperature for the reference subcritical assemblies

Table $8 \mathrm{k}_{\text {eff }}$ values as a function of the fuel and clad temperatures for the reference subcritical assemblies with extra fuel assemblies

Table 9 Comparison of $k_{\text {eff }}$ at different fuel and clad temperatures for the reference subcritical assemblies 



\begin{abstract}
Argonne National Laboratory (ANL) of the United States and Kharkov Institute of Physics and Technology (KIPT) of Ukraine have cooperated on the development, design, and construction of a neutron source facility. The facility was constructed at Kharkov, Ukraine and its commissioning process is underway. It will be used to conduct basic and applied nuclear research, produce medical isotopes, and train young nuclear specialists. The facility has an electron accelerator driven subcritical assembly. The electron beam power is $100 \mathrm{~kW}$ using 100 $\mathrm{MeV}$ electrons. Tungsten or natural uranium is the target material for generating neutrons driving the subcritical assembly. The subcritical assembly is composed of WWR-M2 - Russian fuel assemblies with U-235 enrichment of $19.7 \mathrm{wt} \%$, surrounded by beryllium reflector assembles and graphite blocks. The subcritical assembly is seated in a water tank, which is a part of the primary cooling loop. During normal operation, the water coolant operates at room temperature and the total facility power is $\sim 300 \mathrm{KW}$. The passive safety features of the facility are discussed in in this study. Monte Carlo computer code MCNPX was utilized in the analyses with ENDF/B-VII.0 nuclear data libraries. Negative reactivity temperature feedback was consistently observed, which is important for the facility safety performance. Due to the design of WWR-M2 fuel assemblies, slight water temperature increase and the corresponding water density decrease produce large reactivity drop, which offset the reactivity gain by mistakenly loading an additional fuel assembly. The increase of fuel temperature also causes sufficiently large reactivity decrease. This enhances the facility safety performance because fuel temperature increase provides prompt negative reactivity feedback.
\end{abstract}

The reactivity variation due to an empty fuel position filled by water during the fuel loading process, is examined. Also, the loading mistakes of removing beryllium reflector assemblies and replace them with dummy assemblies were analyzed. In all these circumstances, the reactivity change results do not cause any safety concerns. 


\section{Introduction}

Accelerator driven systems (ADS) are under consideration in the nuclear power fuel cycle scenarios for transmuting actinides and long-lived fission products, and for performing other missions. Several studies and experiments have been conducted to examine and to characterize the accelerator driven sub-critical systems performance. As a part of the collaboration activity between Argonne National Laboratory (ANL) of USA and the National Science Center-Kharkov Institute of Physics and Technology (NSC-KIPT) of Ukraine, a neutron source facility based on the use of an electron accelerator driven sub-critical system [1] was developed, designed, and constructed. The main functions of this facility are the medical isotope production and the support of the Ukraine nuclear industry. Physics experiments and material research will also be carried out utilizing this facility. This facility has been constructed at Kharkov, Ukraine and its commissioning process has been started.

The facility has $100 \mathrm{~kW}$ electron beam using $100 \mathrm{MeV}$ electrons. Tungsten or natural uranium is used as the target material. The electron interactions with the target material produce high energy photons, which generate neutrons through photonuclear reactions with the target material for driving the subcritical system. The WWR-M2 fuel design [2], with U-235 enrichment of $19.7 \mathrm{wt} \%$ is the fuel of the subcritical assembly. The WWR-M2 fuel is used in Kiev research reactor and in other test reactors with water coolant around the world. Beryllium assemblies and graphite blocks were used as reflector to improve the neutron economy. The whole subcritical assembly is seated in a water tank, which is part of the primary cooling system. The radial configuration of the subcritical assembly, reflector and water tank is shown in Figure 1.

The subcritical assembly is designed to operate with the effective neutron multiplication factor $\left(k_{\text {eff }}\right)$ value of less than 0.98 . To keep the $k_{\text {eff }}$ value below 0.98 for fresh loaded assembly at the beginning of the operation, the tungsten target uses 38 fuel assemblies and the uranium target uses 37 fresh fuel assemblies [3]. The maximum fission power is $\sim 200 \mathrm{~kW}$ with the uranium target and $100-\mathrm{KW}$ electron beam power. The water coolant temperature is $\sim 20^{\circ} \mathrm{C}$ during normal operation. The subcritical assembly does not use control rods since it is designed with adequate subcriticality margin.

The temperature reactivity feedback was analyzed in this study, which provides a prompt negative reactivity insuring subcritical operation at all the time including any mistakes during the fuel loading process. Monte Carlo computer program MCNPX [4] was utilized in the analyses with ENDF/B-VII.0 nuclear data libraries [5]. The water coolant temperature changes as well as the corresponding water density changes were varied to determine the reactivity feedback. The water coolant temperature was varied from $\sim 20^{\circ}$ to $90^{\circ} \mathrm{C}$. The fuel temperature was also varied from $\sim 300 \mathrm{~K}$ to $600 \mathrm{~K}$. 


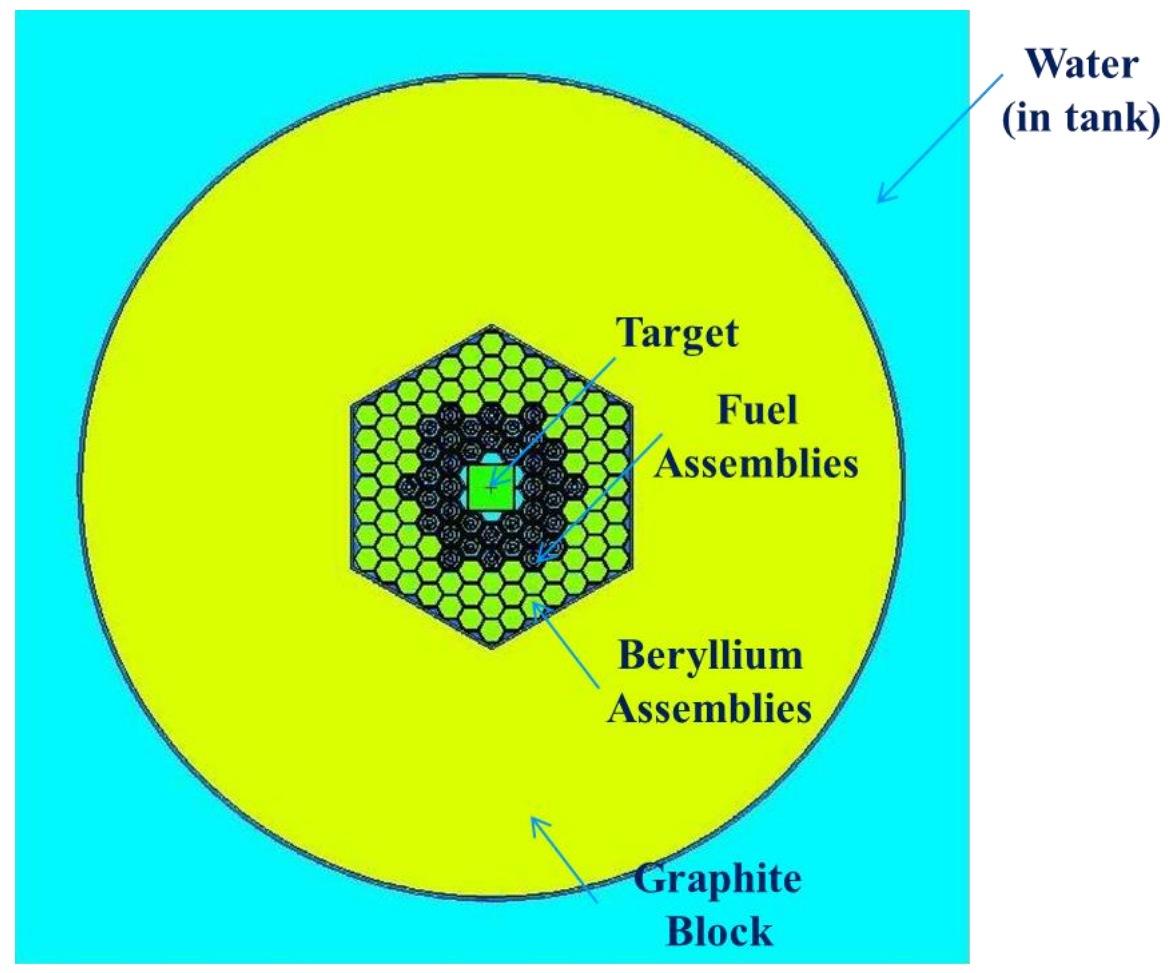

Figure 1. Radial configuration of the subcritical assembly, with reflector and water tank

In the KIPT neutron source facility, the subcritical assembly is loaded by dummy fuel assemblies before loading the fuel assemblies. The dummy fuel assemblies have the same hydraulic characteristics of the real fuel assemblies. This procedure is used to characterize and to calibrate the primary coolant loop. During the fuel loading process, the dummy fuel assemblies are replaced by the real fuel assemblies. The fuel machine replaces one dummy fuel assembly by a real fuel assembly in a sequential process. In this process, the dummy fuel assembly position is filled with water till the fuel machine insert the actual fuel assembly in the empty position. A detailed analysis was performed to determine the reactivity change during this fuel loading process.

In addition, analyses were performed to examine loading mistakes of fuel and beryllium assemblies to determine the subcritical assembly performance. These analyses examined also the transient conditions during the assembly loading process. The transient condition occurs when the assembly in certain position is removed so a fuel or a beryllium assembly can be inserted in this position.

\section{Reactivity worth of the fuel assemblies}

During normal operation, the $k_{\text {eff }}$ value of the subcritical assembly is less than 0.98 , which provides more than $2000 \mathrm{pcm}$ reactivity margin below the critical condition. The $\mathrm{k}_{\text {eff }}$ values of 
the subcritical assembly loaded with different number of fuel assemblies for the tungsten and the uranium targets are shown in Figure 2 through 5.

For the uranium target, the fresh loaded subcritical assembly should have 37 fuel assemblies to keep $k_{\text {eff }}$ value less than 0.98 . The number of fuel assemblies loaded is varied to study the reactivity change. The results in Figure 3 and 5 show that the reactivity worth of a single fuel assembly is $\sim 500 \mathrm{pcm}$. To achieve a critical condition, the subcritical assembly shall be loaded with 42 fuel assemblies, which requires 5 fuel assembles more than the normal loading condition.

For the tungsten target case, the fresh loaded assembly at the beginning of operation has 38 fuel assemblies, and the $k_{\text {eff }}$ value is only $\sim 0.957$. The tungsten material has a strong absorption cross section for the thermal neutrons, and the removal of tungsten target from the subcritical assembly results in $\sim 2000 \mathrm{pcm}$ positive reactivity feedback. On the other hand, the removal of the uranium target results in a small negative reactivity feedback. To keep the assembly $k_{\text {eff }}$ value below 0.98 during all the circumstances even during the tungsten target removal process, the assembly $k_{\text {eff }}$ is kept below 0.96 . The results in Figure 2 and 4 show that the reactivity worth of a single fuel is also $\sim 500 \mathrm{pcm}$. For critical condition, 47 fuel assemblies are required for the subcritical assembly with the tungsten target.

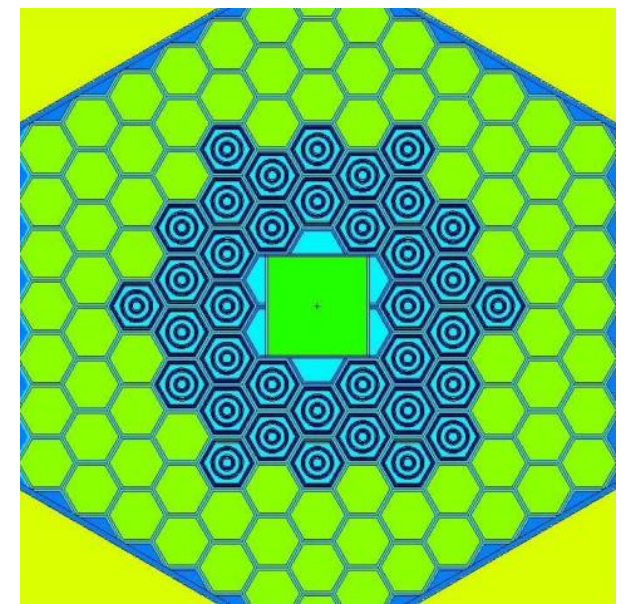

Assembly with 37 fuel assemblies k-eff $=0.95155( \pm 0.00011)$

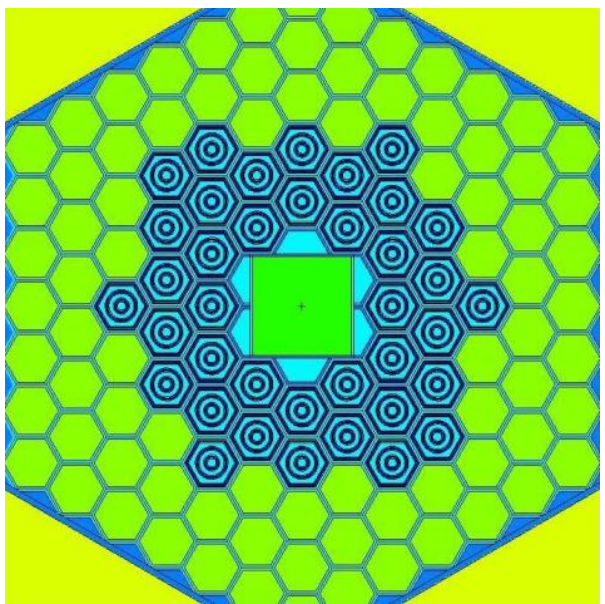

Assembly with 38 fuel assemblies k-eff $=0.95686( \pm 0.00013)$

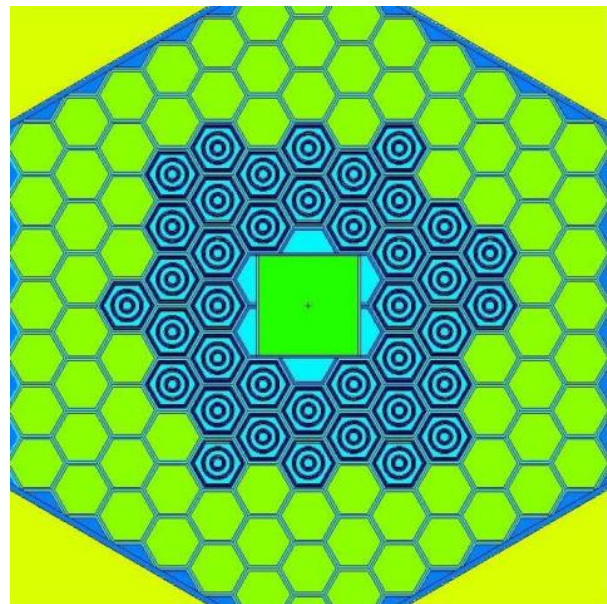

Assembly with 39 fuel assemblies k-eff $=0.96259( \pm 0.00012)$ 


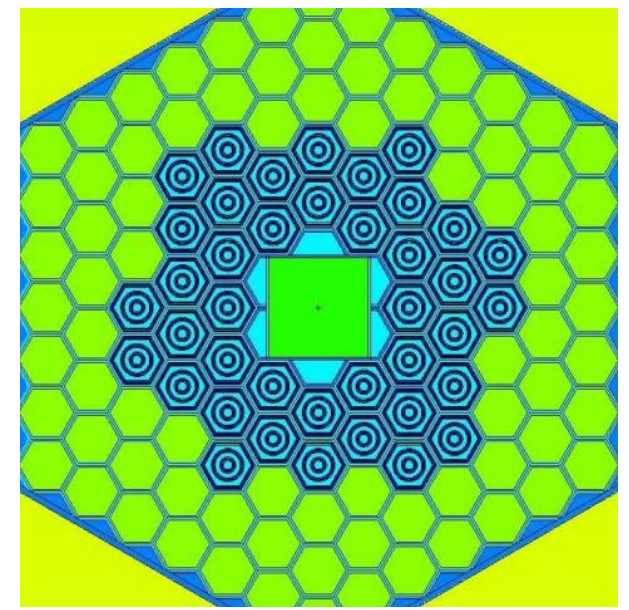

Assembly with 40 fuel assemblies $\mathrm{k}_{\text {eff }}=0.96807( \pm 0.00012)$

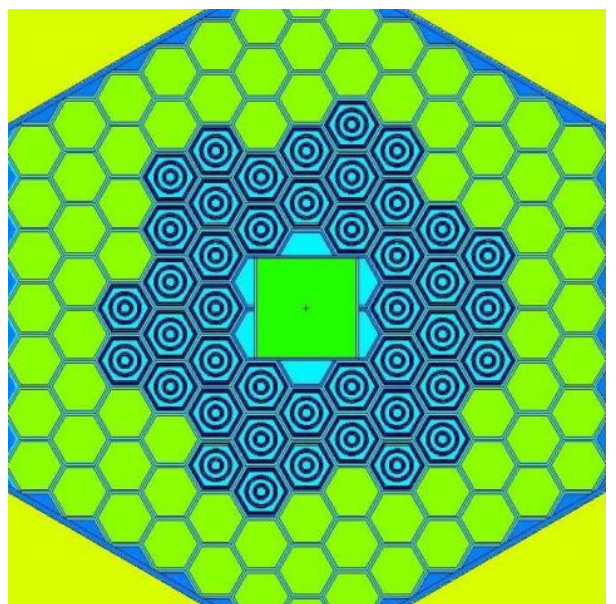

Assembly with 43 fuel assemblies $\mathrm{k}_{\text {eff }}=0.98351( \pm 0.00011)$

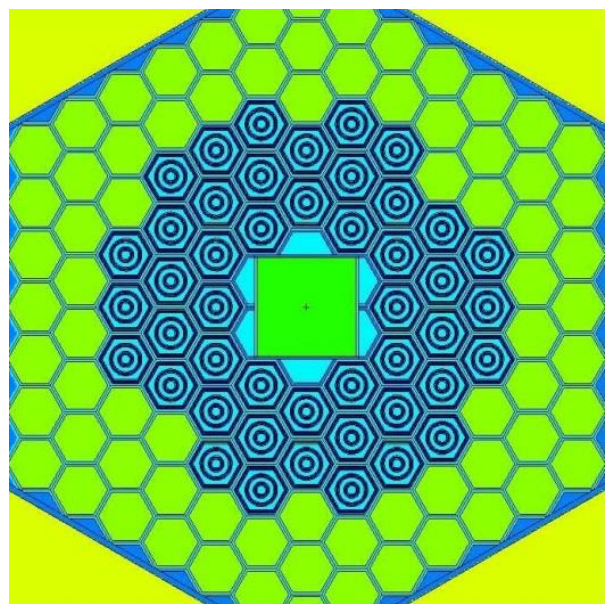

Assembly with 46 fuel assemblies $\mathrm{k}_{\mathrm{eff}}=0.99696( \pm 0.00012)$

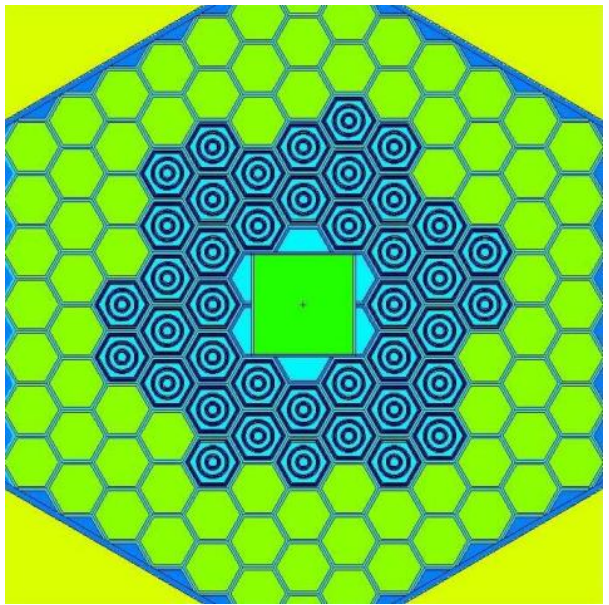

Assembly with 41 fuel assemblies $\mathrm{k}_{\text {eff }}=0.97325( \pm 0.00012)$

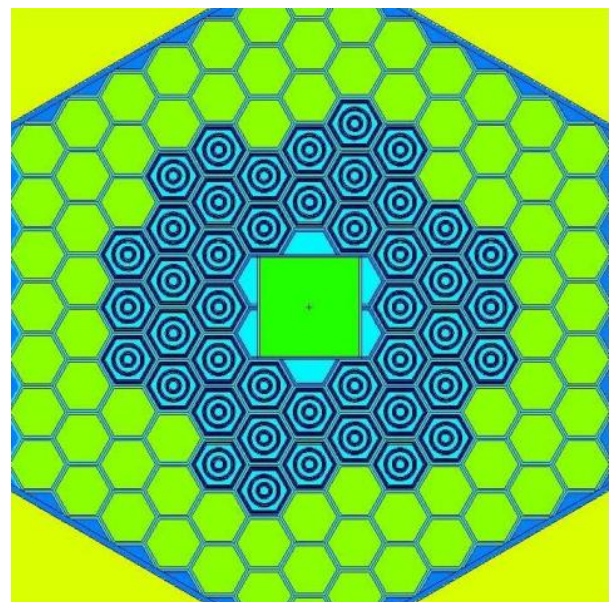

Assembly with 44 fuel assemblies $\mathrm{k}_{\text {eff }}=0.98790( \pm 0.00011)$

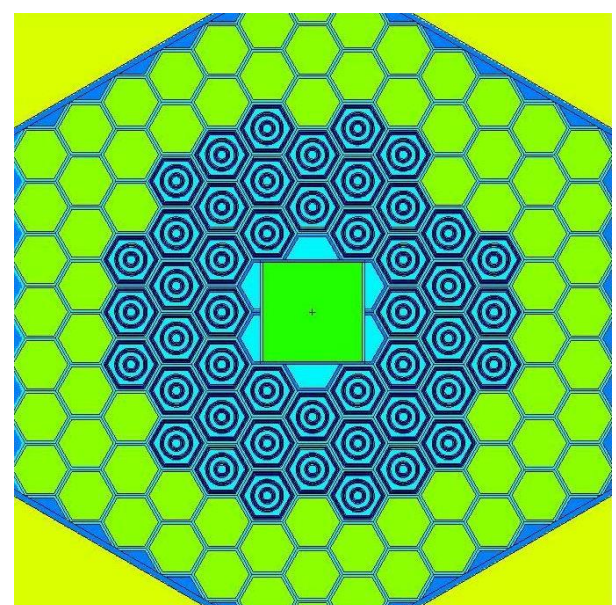

Assembly with 47 fuel assemblies $\mathrm{k}_{\mathrm{eff}}=1.00165( \pm 0.00012)$

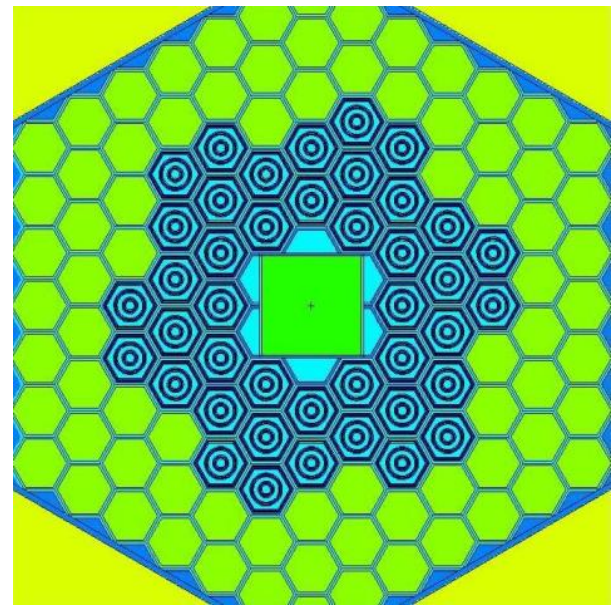

Assembly with 42 fuel assemblies $\mathrm{k}_{\text {eff }}=0.97855( \pm 0.00011)$

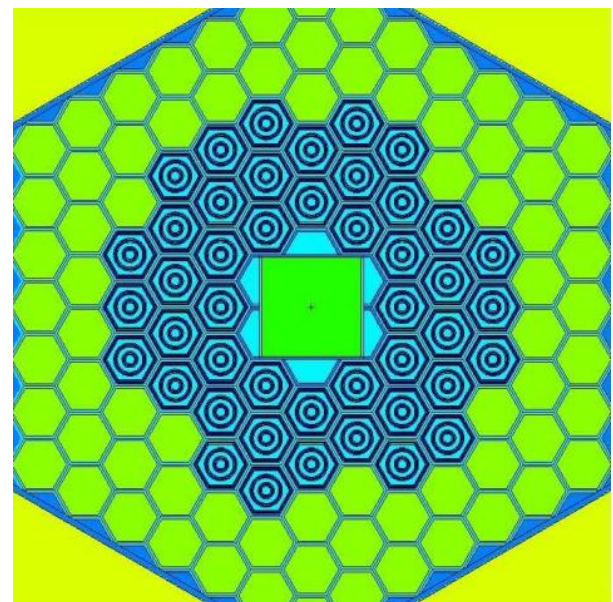

Assembly with 45 fuel assemblies $\mathrm{k}_{\text {eff }}=0.99242( \pm 0.00012)$

Figure 2. KIPT subcritical assembly with the tungsten target and different number of fuel assemblies 


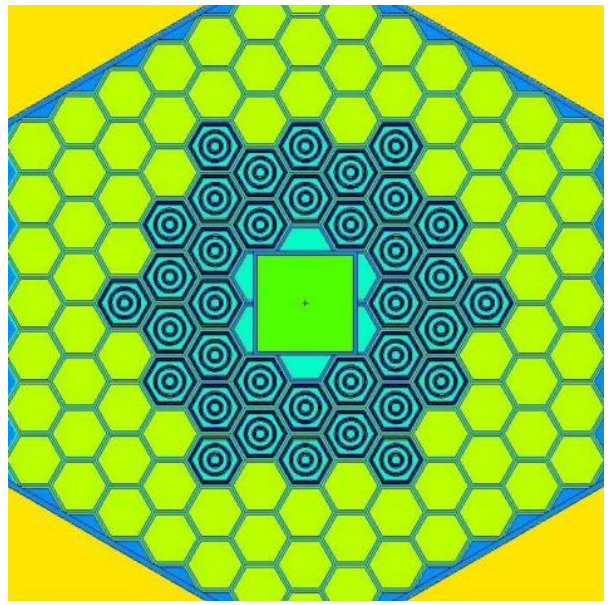

Assembly with 36 fuel assemblies $\mathrm{k}_{\mathrm{eff}}=0.97055( \pm 0.00011)$

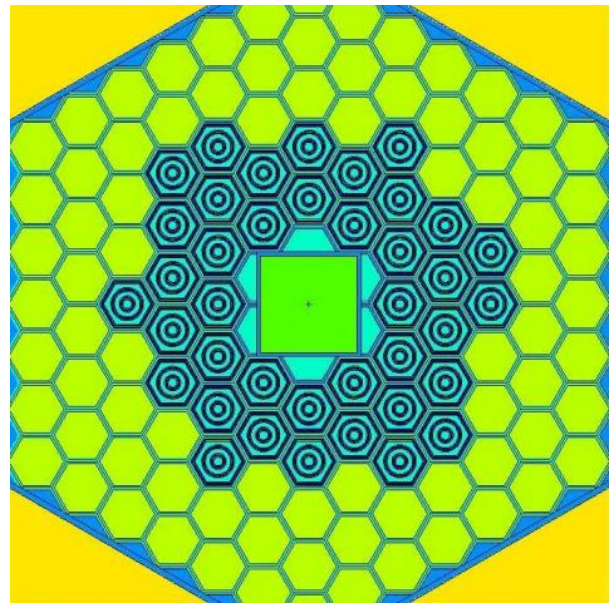

Assembly with 39 fuel assemblies $\mathrm{k}_{\mathrm{eff}}=0.98614( \pm 0.00012)$

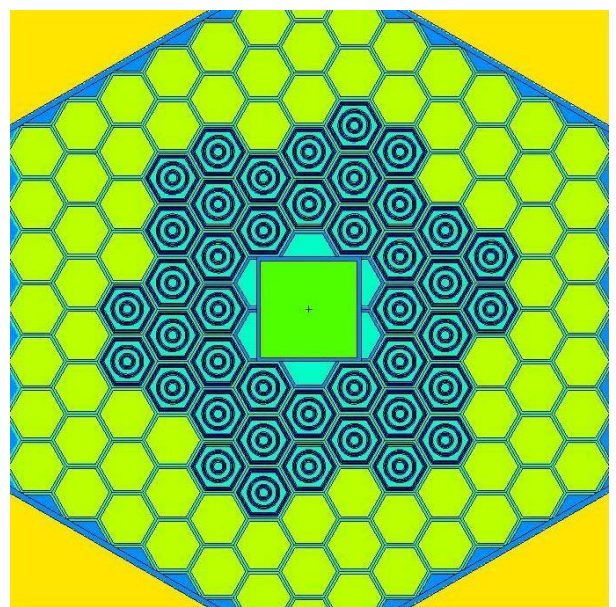

Assembly with 42 fuel assemblies $\mathrm{k}_{\text {eff }}=1.00122( \pm 0.00012)$

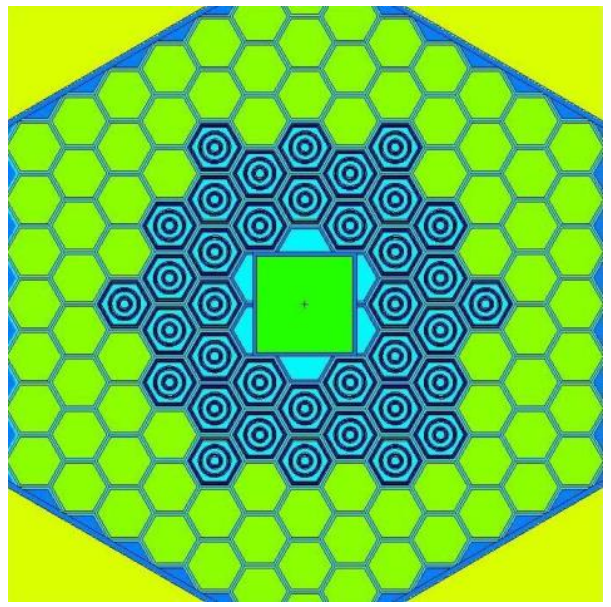

Assembly with 37 fuel assemblies $\mathrm{k}_{\text {eff }}=0.97547( \pm 0.00011)$

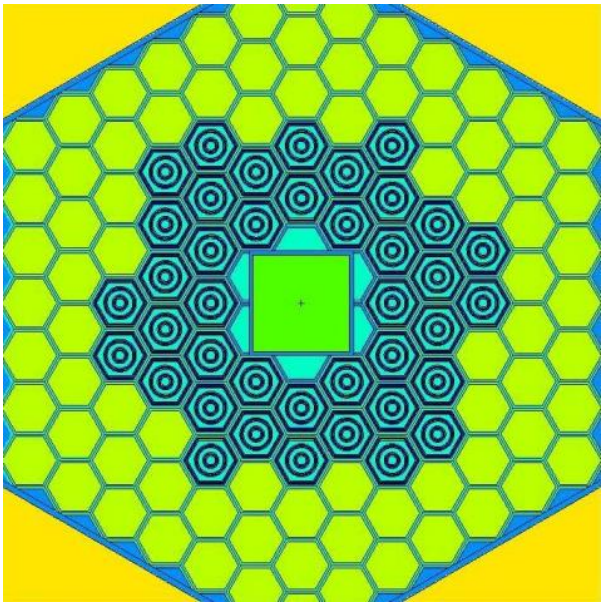

Assembly with 40 fuel assemblies $\mathrm{k}_{\text {eff }}=0.99118( \pm 0.00012)$

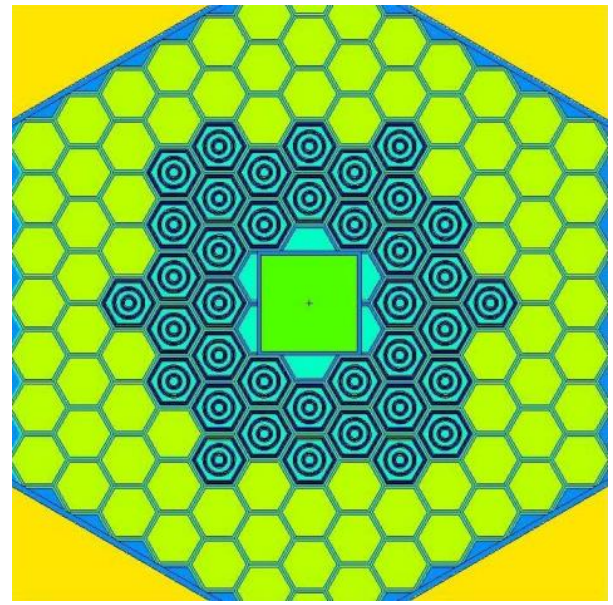

Assembly with 38 fuel assemblies $\mathrm{k}_{\text {eff }}=0.98072( \pm 0.00011)$

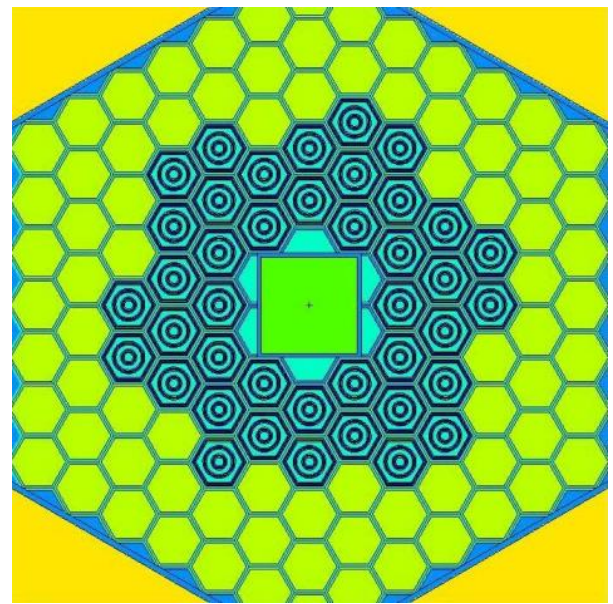

Assembly with 41 fuel assemblies $\mathrm{k}_{\text {eff }}=0.99610( \pm 0.00012)$

Figure 3. KIPT subcritical assembly with the uranium target and different number of fuel assemblies 


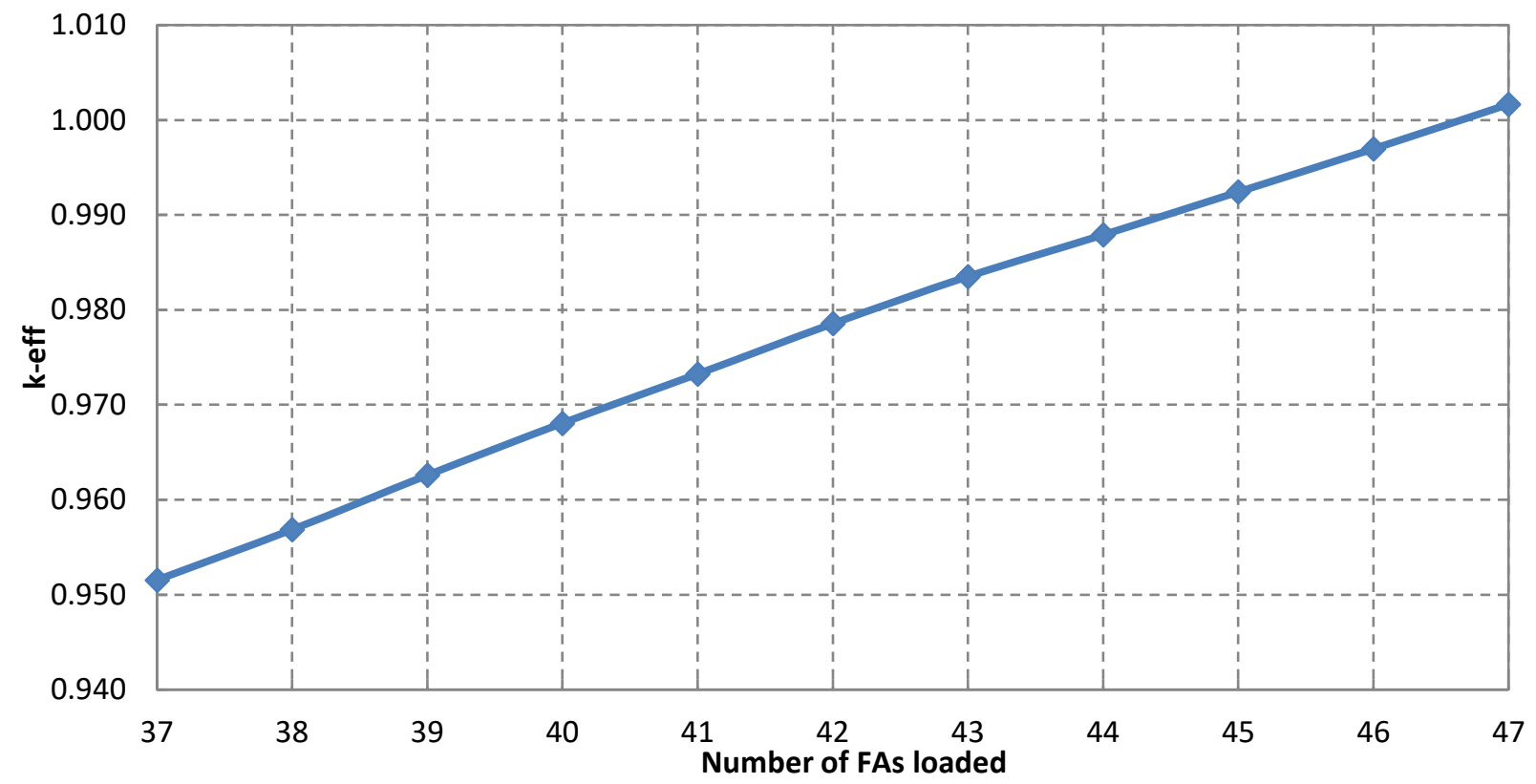

Figure 4. Keff value as a function of the number of the fuel assemblies with the tungsten target

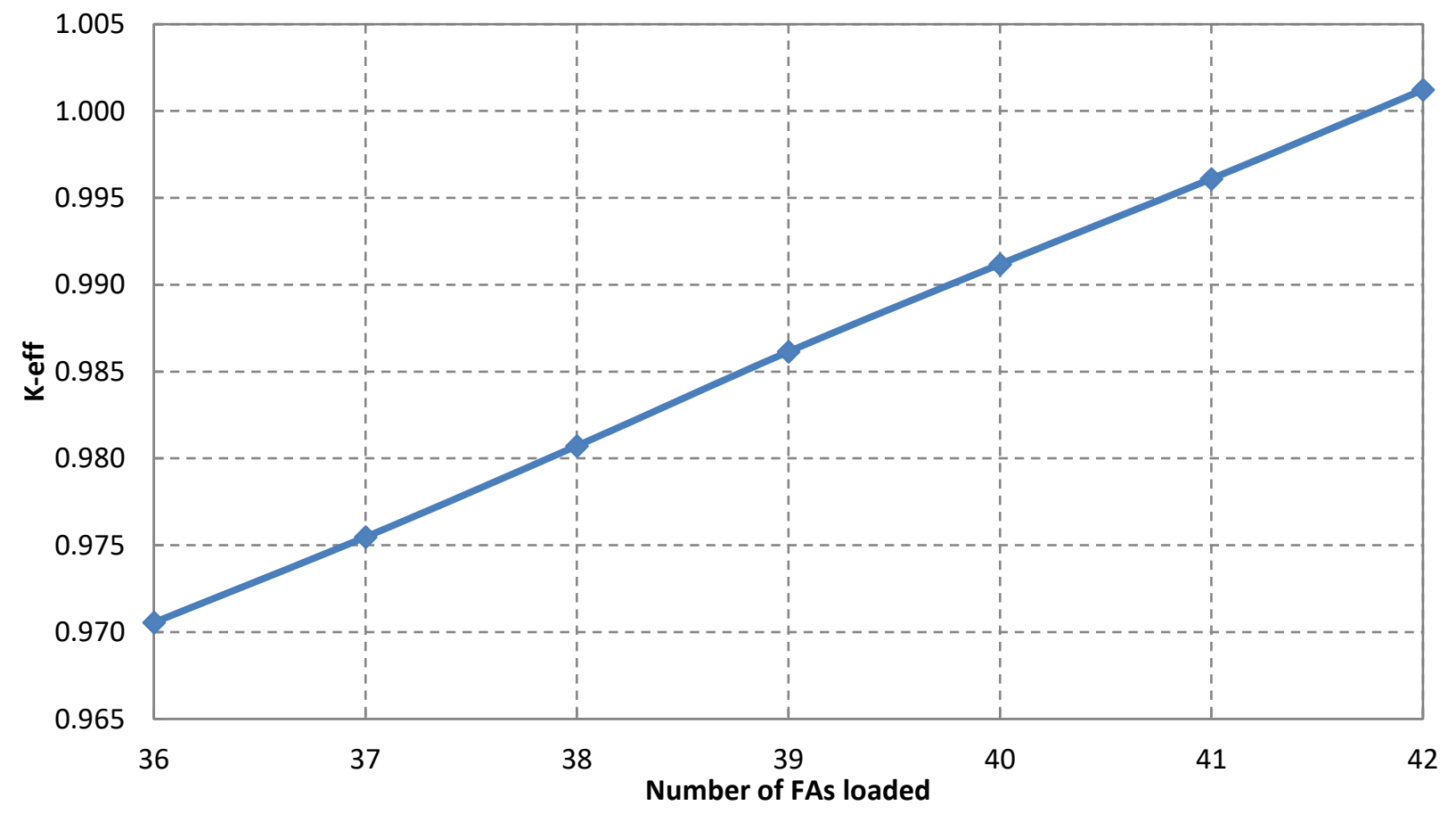

Figure 5. Keff value as a function of the number of the fuel assemblies with the uranium target 


\section{Subcritical assembly reactivity feedback due to the change in the temperature and the density of the water material}

The reference subcritical assembly configurations consist of 38 fuel assemblies with the tungsten target and 37 fuel assemblies with the uranium target to keep the $k_{\text {eff }}$ value $<0.98$ all the time. However, under hypothetical conditions, for example additional fuel assemblies are loaded, the subcritical assembly power will increase and it will be detected. The measured neutron flux values will increase and the measured outlet coolant temperature will also increase. This will provide a warning to stop the operation and check the loaded number of the fuel assemblies. As long as, the $\mathrm{K}_{\text {eff }}$ value is $<1$, the power level will reach certain fixed value depending on the accelerator beam power and the $K_{\text {eff }}$ value. However, the analyses in this section was performed for unrealistic condition, which assume a large number of fuel assemblies were loaded and $\mathrm{K}_{\text {eff }}$ value is greater than 1.0. The goal is to assess the system feedback and the consequences of such situation.

Based on the results from the previous section, 47 fuel assemblies loaded (9 fuel assemblies more than the reference case) with the tungsten target and 42 fuel assemblies loaded ( 5 fuel assemblies more than the reference case) with the uranium target will get Keff value $>1.0$. These two configurations are shown in Figure 6 and used in this analysis.

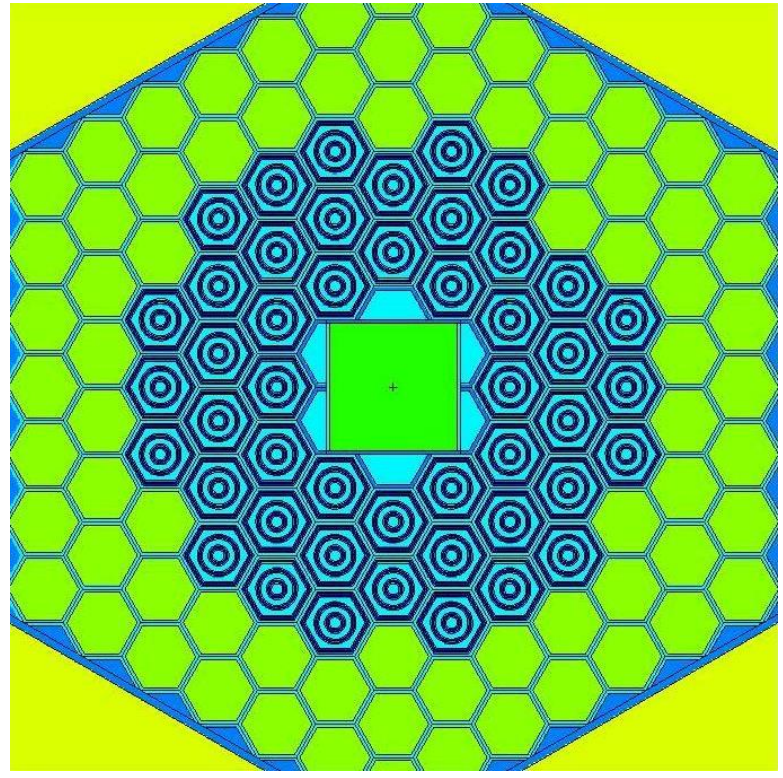

The tungsten target with 47 fuel assemblies laded at room temperature $\mathrm{k}_{\text {eff }}=1.00165( \pm 0.00012)$

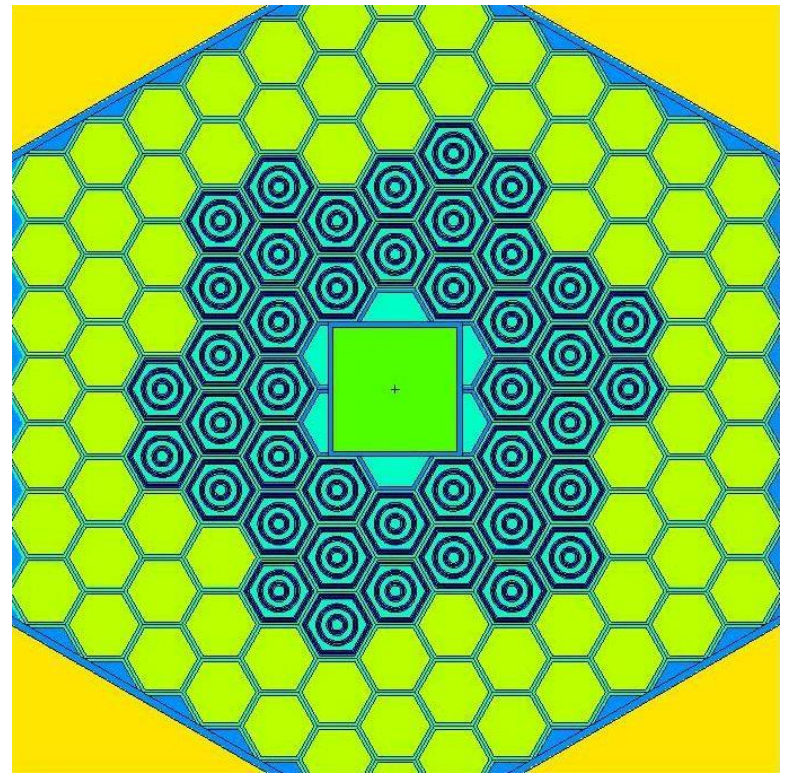

The uranium target with 42 fuel assemblies loaded at room temperature $\mathrm{k}_{\text {eff }}=1.00122( \pm 0.00012)$

Figure 6 Subcritical assembly configurations with keff value greater than 1.0 
The $k_{\text {eff }}$ values of these two configuration were calculated with different water temperature values and the water density was adjusted corresponding to the temperature value. The water density as a function of the temperature is shown in Table 1 . The water density decreases slightly with temperature, before reaching the boiling point. For MCNPX, the ENDF/B-VII.0 nuclear data library has only cross sections for some isotopes at certain temperature values. Therefore, the cross section at the room temperature $(293.6 \mathrm{~K})$ is selected and the temperature tmp card is used to adjust the cross sections.

Table 1. Water density at different temperature

\begin{tabular}{|c|c|}
\hline Temperature & Density $\left(\mathrm{g} / \mathrm{cm}^{3}\right)$ \\
\hline $0 \sim 20^{\circ}$ & $\sim 1.0$ \\
\hline $40^{\circ}$ & 0.9922 \\
\hline $50^{\circ}$ & 0.9881 \\
\hline $60^{\circ}$ & 0.9832 \\
\hline $70^{\circ}$ & 0.9778 \\
\hline $80^{\circ}$ & 0.9718 \\
\hline $90^{\circ}$ & 0.9653 \\
\hline
\end{tabular}

In the KIPT neutron source facility, the fuel region and target assembly have separate coolant loops. Therefore, the temperature of coolant in fuel region and target assembly can be treated separately.

Table 2 and III give the calculated $k_{\text {eff }}$ values as a function of the water temperature. In Table II, the water temperature was simultaneously changed in the target assembly and the fuel region while Table III gives the same results for changing only the water temperature in the fuel region. Comparing the results of

Table 2 and III, the target water temperature change has insignificant impact on the calculated $\mathrm{K}_{\text {eff }}$ values.

The last row of Table 3 has the $\mathrm{K}_{\text {eff }}$ results for changing the water density without the use of the tmp card to adjust the temperature of the cross section data. Comparing the results of the last two rows shows that the change in the $k_{\text {eff }}$ is mainly due to the change of the water density.

These results show that increasing the water temperature from room temperature to 40 ${ }^{\circ} \mathrm{C}$ results in a negative reactivity feedback, which change $\mathrm{K}_{\text {eff }}$ value from $>1$ to $<1$. Such feedback provides a significant safety feature. In addition, if the water temperature reaches 80 
${ }^{\circ} \mathrm{C}$, well below the water boiling point, the negative reactivity feedback is $\sim 676 \mathrm{pcm}$, which is more than the reactivity worth of a single fuel assembly.

Table 2. Keff values as a function of the water temperature of the target assembly and the fuel region for the reference subcritical assemblies with extra fuel assemblies

\begin{tabular}{|c|c|c|c|c|}
\hline \multirow{2}{*}{$\begin{array}{c}\text { Temperature } \\
{ }^{\circ} \mathrm{C}\end{array}$} & \multicolumn{2}{|c|}{$\begin{array}{c}\text { Assembly with the tungsten } \\
\text { target and } 47 \text { fuel assemblies }\end{array}$} & \multicolumn{2}{c|}{$\begin{array}{c}\text { Assembly with the uranium } \\
\text { target and } 42 \text { fuel assemblies }\end{array}$} \\
\cline { 2 - 5 } & $\mathrm{k}_{\text {eff }}$ & $\delta \mathrm{k}_{\text {eff }}$ & $\mathrm{k}_{\text {eff }}$ & $\delta \mathrm{k}_{\text {eff }}$ \\
\hline 20.46 & $\begin{array}{c}1.00165 \\
( \pm 0.00012)\end{array}$ & - & $\begin{array}{c}1.00122 \\
( \pm 0.00012)\end{array}$ & - \\
\hline 40 & $\begin{array}{c}0.99928 \\
( \pm 0.00012)\end{array}$ & -0.00237 & $\begin{array}{c}0.99874 \\
( \pm 0.00011)\end{array}$ & -0.00248 \\
\hline 50 & $\begin{array}{c}0.99853 \\
( \pm 0.00012)\end{array}$ & -0.00308 & $\begin{array}{c}0.99771 \\
( \pm 0.00012)\end{array}$ & -0.00351 \\
\hline 60 & $\begin{array}{c}0.99745 \\
( \pm 0.00011)\end{array}$ & -0.00420 & $\begin{array}{c}0.99668 \\
( \pm 0.00012)\end{array}$ & -0.00454 \\
\hline 70 & $\begin{array}{c}0.99596 \\
( \pm 0.00012)\end{array}$ & -0.00569 & $\begin{array}{c}0.99549 \\
( \pm 0.00013)\end{array}$ & -0.00573 \\
\hline 80 & $\begin{array}{c}0.99465 \\
( \pm 0.00012)\end{array}$ & -0.00700 & $\begin{array}{c}0.99398 \\
( \pm 0.00012)\end{array}$ & -0.00724 \\
\hline 90 & $\begin{array}{c}0.99323 \\
( \pm 0.00012)\end{array}$ & -0.00842 & $\begin{array}{c}0.99260 \\
( \pm 0.00012)\end{array}$ & -0.00862 \\
\hline
\end{tabular}

Table 3. Keff values as a function of the water temperature of the fuel region for the reference subcritical assemblies with extra fuel assemblies

\begin{tabular}{|c|c|c|c|c|}
\hline \multirow{2}{*}{$\begin{array}{c}\text { Temperature, } \\
{ }^{\circ} \mathrm{C}\end{array}$} & \multicolumn{2}{|c|}{$\begin{array}{c}\text { Assembly with the tungsten } \\
\text { target and } 47 \text { fuel assemblies }\end{array}$} & \multicolumn{2}{c|}{$\begin{array}{c}\text { Assembly with the uranium } \\
\text { target and } 42 \text { fuel assemblies }\end{array}$} \\
\cline { 2 - 5 } & $\mathrm{k}_{\text {eff }}$ & $\delta \mathrm{k}_{\text {eff }}$ & $\mathrm{k}_{\text {eff }}$ & $\delta \mathrm{k}_{\text {eff }}$ \\
\hline 20.46 & $\begin{array}{c}1.00165 \\
( \pm 0.00012)\end{array}$ & - & $\begin{array}{c}1.00122 \\
( \pm 0.00012)\end{array}$ & - \\
\hline 40 & $\begin{array}{c}0.99949 \\
( \pm 0.00011)\end{array}$ & -0.00216 & $\begin{array}{c}0.99885 \\
( \pm 0.00011)\end{array}$ & -0.00237 \\
\hline 50 & $\begin{array}{c}0.99866 \\
( \pm 0.00012)\end{array}$ & -0.00299 & $\begin{array}{c}0.99816 \\
( \pm 0.00012)\end{array}$ & -0.00306 \\
\hline 60 & $\begin{array}{c}0.99757 \\
( \pm 0.00011)\end{array}$ & -0.00408 & $\begin{array}{c}0.99669 \\
( \pm 0.00012)\end{array}$ & -0.00453 \\
\hline 70 & $\begin{array}{c}0.99632 \\
( \pm 0.00012)\end{array}$ & -0.00533 & $\begin{array}{c}0.99553 \\
( \pm 0.00012)\end{array}$ & -0.00569 \\
\hline 80 & $\begin{array}{c}0.99489 \\
( \pm 0.00012)\end{array}$ & -0.00676 & $\begin{array}{c}0.99446 \\
( \pm 0.00012)\end{array}$ & -0.00676 \\
\hline 90 & $\begin{array}{c}0.99352 \\
( \pm 0.00012)\end{array}$ & -0.00813 & $\begin{array}{c}0.99299 \\
( \pm 0.00011)\end{array}$ & -0.00823 \\
\hline
\end{tabular}




\begin{tabular}{|c|c|c|c|c|}
\hline $90^{*}$ & $\begin{array}{c}0.99349 \\
( \pm 0.00012)\end{array}$ & -0.00816 & $\begin{array}{c}0.99330 \\
( \pm 0.00011)\end{array}$ & -0.00792 \\
\hline
\end{tabular}

${ }^{*}$ Only the density of water coolant is changed, no tmp cards used to adjust the cross section data

The $\mathrm{K}_{\text {eff }}$ of the reference configurations were also analyzed for the water temperature change with the corresponding density change and the results are given in Table 4 and V. Also for the reference configurations, the increase of the water temperature results in a negative reactivity feedback. As expected, the reactivity change values are smaller than the previous configurations with additional fuel assemblies. Such results are expected because less fuel material means less reactions.

Table 4. Keff values as a function of the water temperature of the target assembly and the fuel region for the reference subcritical assemblies.

\begin{tabular}{|c|c|c|c|c|}
\hline \multirow{2}{*}{$\begin{array}{c}\text { Temperature, } \\
{ }^{\circ} \mathrm{C}\end{array}$} & \multicolumn{2}{|c|}{$\begin{array}{c}\text { Reference configuration } \\
\text { with the tungsten target }\end{array}$} & \multicolumn{2}{c|}{$\begin{array}{c}\text { Reference configuration } \\
\text { with the uranium target }\end{array}$} \\
\cline { 2 - 5 } & $\mathrm{k}_{\text {eff }}$ & $\delta \mathrm{k}_{\text {eff }}$ & $\mathrm{k}_{\text {eff }}$ & $\delta \mathrm{k}_{\text {eff }}$ \\
\hline 20.46 & $\begin{array}{c}0.95686 \\
( \pm 0.00013)\end{array}$ & - & $\begin{array}{c}0.97547 \\
( \pm 0.00011)\end{array}$ & - \\
\hline 40 & $\begin{array}{c}0.95507 \\
( \pm 0.00011)\end{array}$ & -0.00181 & $\begin{array}{c}0.97366 \\
( \pm 0.00011)\end{array}$ & -0.00181 \\
\hline 50 & $\begin{array}{c}0.95416 \\
( \pm 0.00012)\end{array}$ & -0.00270 & $\begin{array}{c}0.97269 \\
( \pm 0.00012)\end{array}$ & -0.00278 \\
\hline 60 & $\begin{array}{c}0.95272 \\
( \pm 0.00012)\end{array}$ & -0.00414 & $\begin{array}{c}0.97156 \\
( \pm 0.00011)\end{array}$ & -0.00391 \\
\hline 70 & $\begin{array}{c}0.95180 \\
( \pm 0.00012)\end{array}$ & -0.00506 & $\begin{array}{c}0.97047 \\
( \pm 0.00012)\end{array}$ & -0.00500 \\
\hline 80 & $\begin{array}{c}0.95038 \\
( \pm 0.00012)\end{array}$ & -0.00648 & $\begin{array}{c}0.96902 \\
( \pm 0.00013)\end{array}$ & -0.00645 \\
\hline 90 & $\begin{array}{c}0.94908 \\
( \pm 0.00012)\end{array}$ & -0.00778 & $\begin{array}{c}0.96760 \\
( \pm 0.00012)\end{array}$ & -0.00787 \\
\hline
\end{tabular}


Table 5. Keff values as a function of the water temperature of the fuel region for the reference subcritical assemblies.

\begin{tabular}{|c|c|c|c|c|}
\hline \multirow{2}{*}{$\begin{array}{c}\text { Temperature, } \\
{ }^{\circ} \mathrm{C}\end{array}$} & \multicolumn{2}{|c|}{$\begin{array}{c}\text { Reference configuration } \\
\text { with the tungsten target }\end{array}$} & \multicolumn{2}{c|}{$\begin{array}{c}\text { Reference configuration } \\
\text { with the uranium target }\end{array}$} \\
\cline { 2 - 5 } & $\mathrm{k}_{\text {eff }}$ & $\delta \mathrm{k}_{\text {eff }}$ & $\mathrm{k}_{\text {eff }}$ & $\delta \mathrm{k}_{\text {eff }}$ \\
\hline 20.46 & $\begin{array}{c}0.95686 \\
( \pm 0.00013)\end{array}$ & - & $\begin{array}{c}0.97547 \\
( \pm 0.00011)\end{array}$ & - \\
\hline 40 & $\begin{array}{c}0.95512 \\
( \pm 0.00012)\end{array}$ & -0.00174 & $\begin{array}{c}0.97371 \\
( \pm 0.00012)\end{array}$ & -0.00176 \\
\hline 50 & $\begin{array}{c}0.95422 \\
( \pm 0.00012)\end{array}$ & -0.00264 & $\begin{array}{c}0.97259 \\
( \pm 0.00012)\end{array}$ & -0.00288 \\
\hline 60 & $\begin{array}{c}0.95321 \\
( \pm 0.00012)\end{array}$ & -0.00365 & $\begin{array}{c}0.97199 \\
( \pm 0.00012)\end{array}$ & -0.00348 \\
\hline 70 & $\begin{array}{c}0.95196 \\
( \pm 0.00012)\end{array}$ & -0.00490 & $\begin{array}{c}0.97078 \\
( \pm 0.00011)\end{array}$ & -0.00469 \\
\hline 80 & $\begin{array}{c}0.95076 \\
( \pm 0.00012)\end{array}$ & -0.00610 & $\begin{array}{c}0.96929 \\
( \pm 0.00012)\end{array}$ & -0.00618 \\
\hline 90 & $\begin{array}{c}0.94928 \\
( \pm 0.00012)\end{array}$ & -0.00758 & $\begin{array}{c}0.96812 \\
( \pm 0.00013)\end{array}$ & -0.00735 \\
\hline 90 & $\begin{array}{c}0.94958 \\
( \pm 0.00012)\end{array}$ & -0.00728 & $\begin{array}{c}0.96802 \\
( \pm 0.00012)\end{array}$ & -0.00745 \\
\hline
\end{tabular}

${ }^{*}$ Only the density of water coolant is changed, no tmp cards used to adjust the cross section data

\section{Subcritical assembly reactivity feedback due to the change in the fuel material temperature}

The results and analyses of the previous section show that the decrease of water density due to the temperature increase is sufficient to keep the system in a subcritical state even if additional fuel assembles are loaded. However, the fuel material temperature will increase first and it will reach higher values. To examine the reactivity impact of this temperature increase, MCNPX analyses were performed with different fuel temperatures without changing the temperature of the water and clad materials. In fact, the fuel temperature increases instantaneously with the power increase before the temperature increase of the clad and water materials.

The tungsten target assembly with 47 fuel assemblies and the uranium target assembly with 42 fuel assemblies, which have the k-eff above 1.0 at room temperature, were selected for this analyses. The ENDF/B-VII.0 nuclear data library of MCNPX has cross sections sets 
corresponding to certain temperatures. These temperatures were used for the fuel material to match the data library. The calculated $k_{\text {eff }}$ values are given in Table 6.

Table 6. Keff values as a function of the fuel temperature for the reference subcritical assemblies with extra fuel assemblies

\begin{tabular}{|c|c|c|c|c|}
\hline $\begin{array}{c}\text { Fuel } \\
\text { Temperature, } \\
\mathrm{K}\end{array}$ & \multicolumn{2}{|c|}{$\begin{array}{c}\text { Assembly with the tungsten } \\
\text { target and 47 fuel assemblies }\end{array}$} & \multicolumn{2}{|c|}{$\begin{array}{c}\text { Assembly with the uranium } \\
\text { target and 42 fuel assemblies }\end{array}$} \\
\cline { 2 - 5 } & $\mathrm{k}_{\text {eff }}$ & $\delta \mathrm{k}_{\text {eff }}$ & $\mathrm{k}_{\text {eff }}$ & $\delta \mathrm{k}_{\text {eff }}$ \\
\hline 293.6 & $\begin{array}{c}1.00165 \\
( \pm 0.00012)\end{array}$ & - & $\begin{array}{c}1.00122 \\
( \pm 0.00012)\end{array}$ & - \\
\hline 600 & $\begin{array}{c}0.99592 \\
( \pm 0.00011)\end{array}$ & -0.00573 & $\begin{array}{c}0.99546 \\
( \pm 0.00012)\end{array}$ & -0.00576 \\
\hline 900 & $\begin{array}{c}0.99159 \\
( \pm 0.00011)\end{array}$ & -0.01006 & $\begin{array}{c}0.99156 \\
( \pm 0.00012)\end{array}$ & -0.00966 \\
\hline 1200 & $\begin{array}{c}0.98858 \\
( \pm 0.00012)\end{array}$ & -0.01307 & $\begin{array}{c}0.98814 \\
( \pm 0.00011)\end{array}$ & -0.01308 \\
\hline 2500 & $\begin{array}{c}0.97815 \\
( \pm 0.00012)\end{array}$ & -0.02350 & $\begin{array}{c}0.97844 \\
( \pm 0.00012)\end{array}$ & -0.02278 \\
\hline
\end{tabular}

The WWR-M2 fuel design has $\mathrm{UO}_{2}$ smeared in aluminum matrix, and its melting temperature is $\sim 933 \mathrm{~K}$. The $\mathrm{k}_{\text {eff }}$ results shows that increasing the fuel temperature to $600 \mathrm{~K}$, well below the melting point results in a negative reactivity feedback of $\sim 570 \mathrm{pcm}$. This negative reactivity decreases $k_{\text {eff }}$ to less than 1.0 , a subcritical status.

The results of this section and the previous one show that the temperature increase of the subcritical assembly materials produces negative reactivity feedback. This negative reactivity feedback is large enough to keep a subcritical state even if additional fuel assemblies are loaded by mistake increasing $\mathrm{K}_{\text {eff }}$ greater than 1.0 at room temperature.

Similar analyses were performed for the reference configurations, the tungsten target with 38 fuel assemblies and the uranium target with 37 fuel assemblies. The obtained $k_{\text {eff }}$ results are shown in Table 7. Again, the increase of the fuel material temperature results in a significant negative reactivity feedback.

In order to examine the effect of the clad temperature feedback, another analyses were performed. In these analyses, both fuel and clad temperatures were changed. Since the clad material is aluminum with high thermal conductivity, the fuel and clad temperatures are kept at the same temperature, while the water coolant was kept at room temperature. The calculated $k_{\text {eff }}$ values as a function of the fuel and clad temperature are shown in Table 8 and IX. Comparing these results with the previous results where the clad temperature was not changed 
as shown in Table 6 and VII, the k-eff values at the same fuel temperature is about the same within the statistic errors of the Monte Carlo calculations. This shows that the Doppler effect of the cladding material does not play an important reactivity role.

Table 7. keff values as a function of the fuel temperature for the reference subcritical assemblies

\begin{tabular}{|c|c|c|c|c|}
\hline $\begin{array}{c}\text { Fuel } \\
\text { Temperature, } \\
\mathrm{K}\end{array}$ & \multicolumn{2}{|c|}{$\begin{array}{c}\text { Reference configuration } \\
\text { with the tungsten target }\end{array}$} & \multicolumn{2}{c|}{$\begin{array}{c}\text { Reference configuration } \\
\text { with the uranium target }\end{array}$} \\
\cline { 2 - 5 } & $\mathrm{k}_{\text {eff }}$ & $\delta \mathrm{k}_{\text {eff }}$ & $\mathrm{k}_{\text {eff }}$ & $\delta \mathrm{k}_{\text {eff }}$ \\
\hline 293.6 & $\begin{array}{c}0.95686 \\
( \pm 0.00013)\end{array}$ & - & $\begin{array}{c}0.97547 \\
( \pm 0.00011)\end{array}$ & - \\
\hline 600 & $\begin{array}{c}0.95209 \\
\pm 0.00013)\end{array}$ & -0.00477 & $\begin{array}{c}0.97039 \\
( \pm 0.00012)\end{array}$ & -0.00508 \\
\hline 900 & $\begin{array}{c}0.94815 \\
\pm 0.00012)\end{array}$ & -0.00871 & $\begin{array}{c}0.96645 \\
\pm 0.00012)\end{array}$ & -0.00902 \\
\hline 1200 & $\begin{array}{c}0.94522 \\
( \pm 0.00011)\end{array}$ & -0.01164 & $\begin{array}{c}0.96356 \\
\pm 0.00012)\end{array}$ & -0.01191 \\
\hline 2500 & $\begin{array}{c}0.93565 \\
\pm 0.00012)\end{array}$ & -0.02121 & $\begin{array}{c}0.95412 \\
\pm 0.00012)\end{array}$ & -0.02135 \\
\hline
\end{tabular}

Table 8. Keff values as a function of the fuel and clad temperatures for the reference subcritical assemblies with extra fuel assemblies

\begin{tabular}{|c|c|c|c|c|}
\hline $\begin{array}{c}\text { Fuel \& clad } \\
\text { Temperature } \\
\mathrm{K}\end{array}$ & \multicolumn{2}{|c|}{ Tungsten target with 47 FAs } & \multicolumn{2}{c|}{ Uranium target with 42 FAs } \\
\cline { 2 - 5 } & $\mathrm{k}_{\text {eff }}$ & $\delta \mathrm{k}_{\text {eff }}$ & $\mathrm{k}_{\text {eff }}$ & $\delta \mathrm{k}_{\text {eff }}$ \\
\hline 293.6 & $\begin{array}{c}1.00165 \\
( \pm 0.00012)\end{array}$ & - & $\begin{array}{c}1.00122 \\
( \pm 0.00012)\end{array}$ & \\
\hline 600 & $\begin{array}{c}0.99586 \\
( \pm 0.00013)\end{array}$ & -0.00579 & $\begin{array}{c}0.99553 \\
( \pm 0.00011)\end{array}$ & -0.00569 \\
\hline 900 & $\begin{array}{c}0.99184 \\
( \pm 0.00012)\end{array}$ & -0.00981 & $\begin{array}{c}0.99138 \\
( \pm 0.00011)\end{array}$ & -0.00984 \\
\hline 1200 & $\begin{array}{c}0.98827 \\
( \pm 0.00012)\end{array}$ & -0.01338 & $\begin{array}{c}0.98829 \\
( \pm 0.00013)\end{array}$ & -0.01293 \\
\hline 2500 & $\begin{array}{c}0.97805 \\
( \pm 0.00012)\end{array}$ & -0.02360 & $\begin{array}{c}0.97814 \\
( \pm 0.00011)\end{array}$ & -0.02308 \\
\hline
\end{tabular}

\section{Reactivity change during fuel loading process}

The subcritical assembly of the KIPT neutron source facility has a loading capacity of 120 hexagonal assemblies surrounding the target assembly. The fully loaded fresh subcritical assembly with the tungsten target assembly has 38 fuel assemblies and 82 beryllium assemblies and with the uranium target assembly has 37 fuel assemblies and 83 beryllium assemblies. At the beginning of the loading process, the beryllium reflector assemblies will be loaded first at the pre-determined locations, while the fuel locations are loaded with dummy 
assemblies, as shown in Figure 7. In the fuel loading process, the dummy assemblies are replaced by fuel assemblies one by one, until all the fuel assemblies are loaded.

Table 9. Comparison of $k_{\text {eff }}$ at different fuel and clad temperatures for the reference subcritical assemblies

\begin{tabular}{|c|c|c|c|c|}
\hline $\begin{array}{c}\text { Fuel \& clad } \\
\text { Temperature } \\
\mathrm{K}\end{array}$ & \multicolumn{2}{|c|}{ Tungsten target with 38 FAs } & \multicolumn{2}{|c|}{ Uranium target with 37 FAs } \\
\cline { 2 - 5 } & $\mathrm{k}_{\text {eff }}$ & $\delta \mathrm{k}_{\text {eff }}$ & $\mathrm{k}_{\text {eff }}$ & $\delta \mathrm{k}_{\text {eff }}$ \\
\hline 293.6 & $\begin{array}{c}0.95686 \\
( \pm 0.00013)\end{array}$ & - & $\begin{array}{c}0.97547 \\
( \pm 0.00011)\end{array}$ & - \\
\hline 600 & $\begin{array}{c}0.95206 \\
\pm 0.00013)\end{array}$ & -0.00480 & $\begin{array}{c}0.97055 \\
( \pm 0.00012)\end{array}$ & -0.00492 \\
\hline 900 & $\begin{array}{c}0.94832 \\
( \pm 0.00012)\end{array}$ & -0.00854 & $\begin{array}{c}0.96671 \\
( \pm 0.00011)\end{array}$ & -0.00876 \\
\hline 1200 & $\begin{array}{c}0.94511 \\
( \pm 0.00012)\end{array}$ & -0.01175 & $\begin{array}{c}0.96358 \\
( \pm 0.00012)\end{array}$ & -0.01189 \\
\hline 2500 & $\begin{array}{c}0.93614 \\
\pm 0.00012)\end{array}$ & -0.02072 & $\begin{array}{c}0.95424 \\
( \pm 0.00011)\end{array}$ & -0.02123 \\
\hline
\end{tabular}

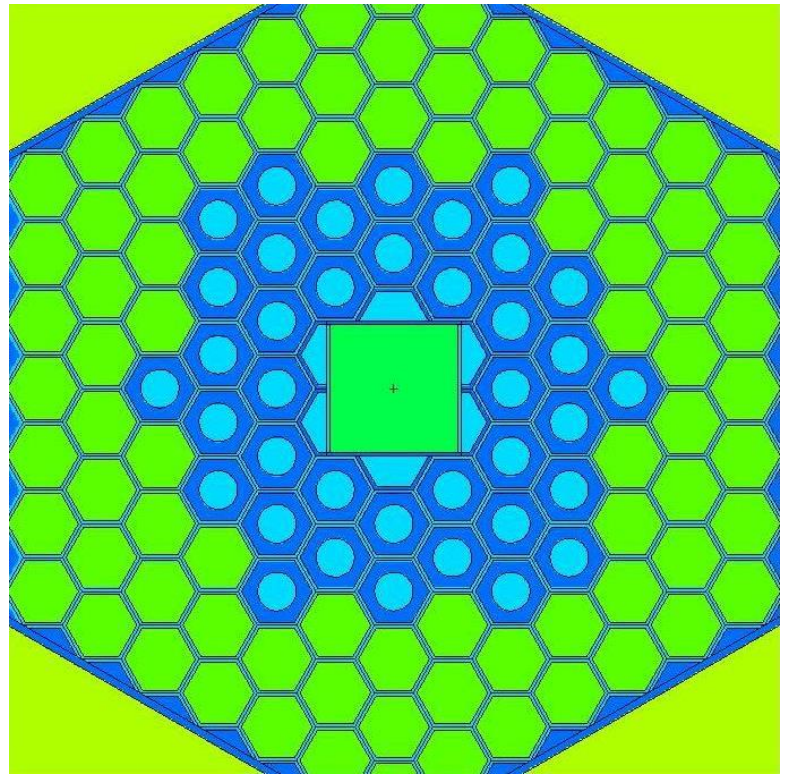

Tungsten target assembly with 82 beryllium assembly and 38 dummy assemblies

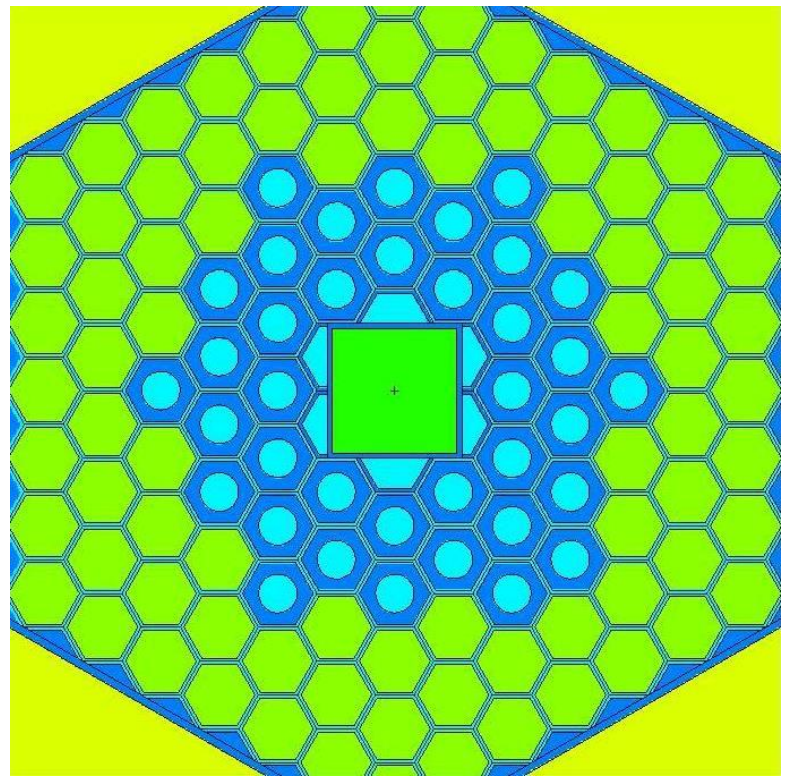

Uranium target assembly with 83 beryllium assembly and 37 dummy assemblies

Figure 7. Radial configurations of the KIPT subcritical assembly at the beginning of fuel loading process, with beryllium and dummy assemblies loaded

During the fuel loading process, the subcritical assembly will have a mixture of fuel and dummy assemblies. The $k_{\text {eff }}$ value during the initial loading process is shown in 
Figure 8 for both tungsten and uranium target as a function of the loaded number of fuel assemblies. It can be seen that the k-eff increases with the number of fuel assemblies, and it is always lower than the reference final value. However, during the fuel loading process, a dummy assembly will be removed so this location will be filled with water before a fuel assembly is inserted. Analysis was performed to examine the impact on the $\mathrm{K}_{\text {eff }}$ value during this transition step.

This analysis was performed for the fuel loading of the last fuel assembly of the reference configurations with tungsten and uranium targets. At this fuel loading step, The subcritical assembly has the largest number of fuel assemblies and the largest $k_{\text {eff }}$ value before the insertion of the last fuel assembly. The obtained results are shown in

Figure 9 and 10. For both configurations, when the dummy assembly is removed before inserting the fuel assembly, the increase in the k-eff values is insignificant. These increases are within the statistic error of the calculations. Therefore, the reactivity increase during the fuel loading process is insignificant and it does not cause any safety concern.

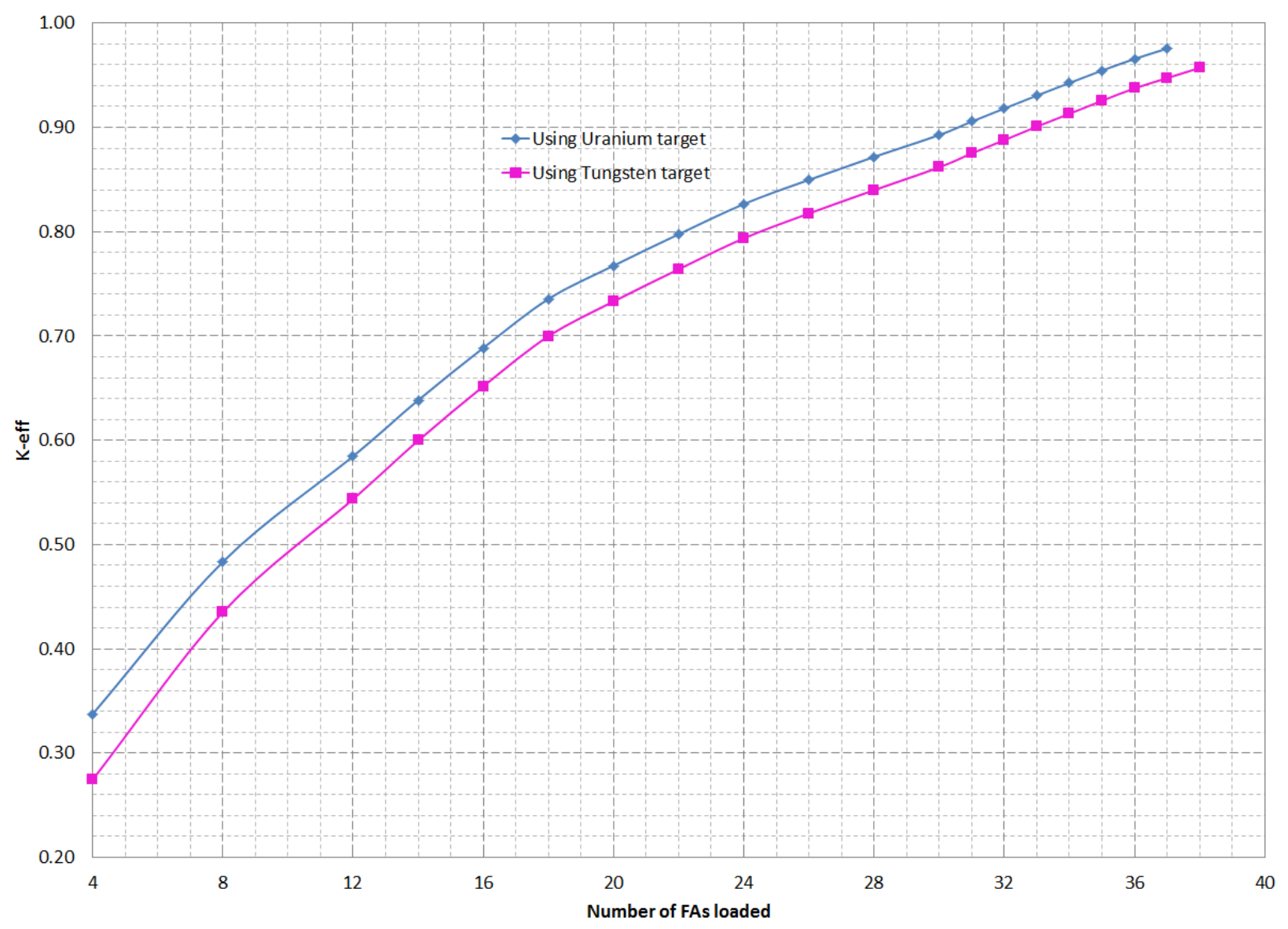

Figure 8. k-eff curve during the initial loading process, for tungsten and uranium target cases 


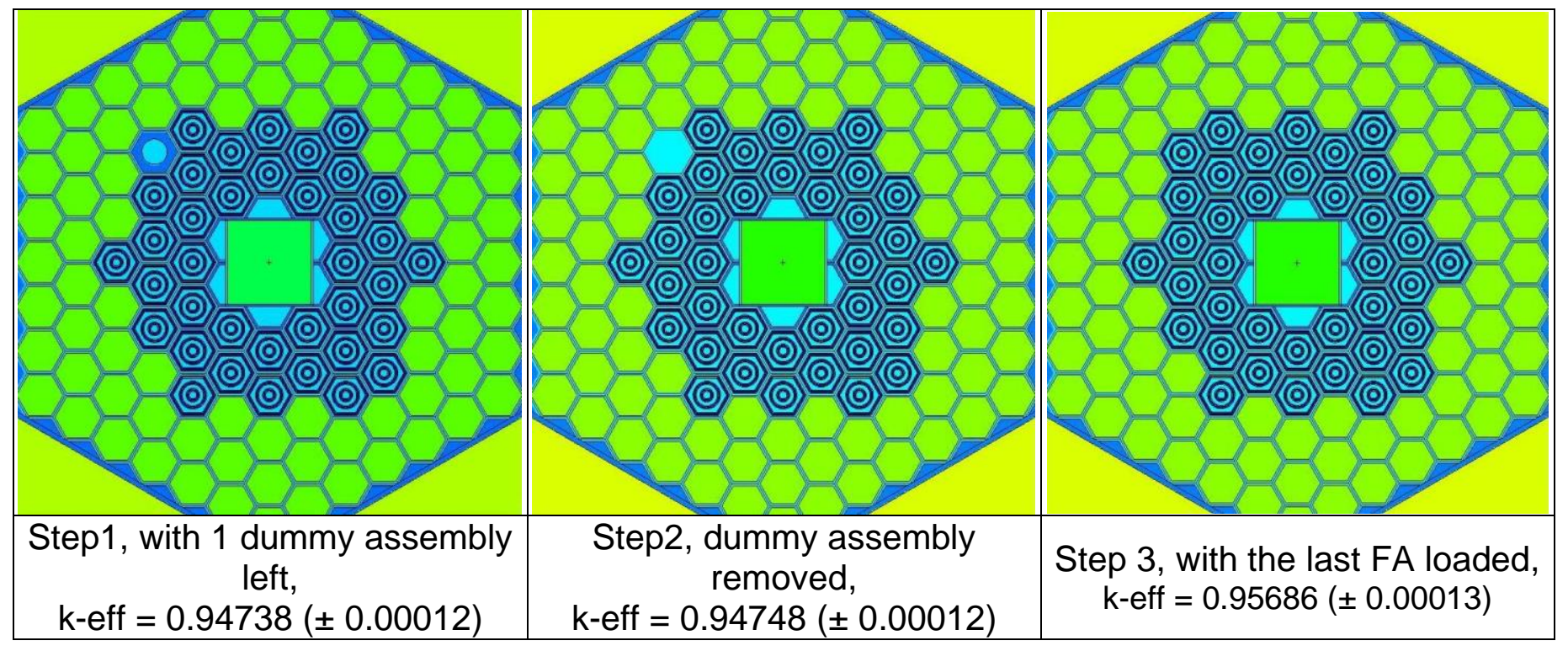

Figure 9. Subcritical assembly configurations with the tungsten target of the KIPT neutron source facility during the last fuel assembly loading process

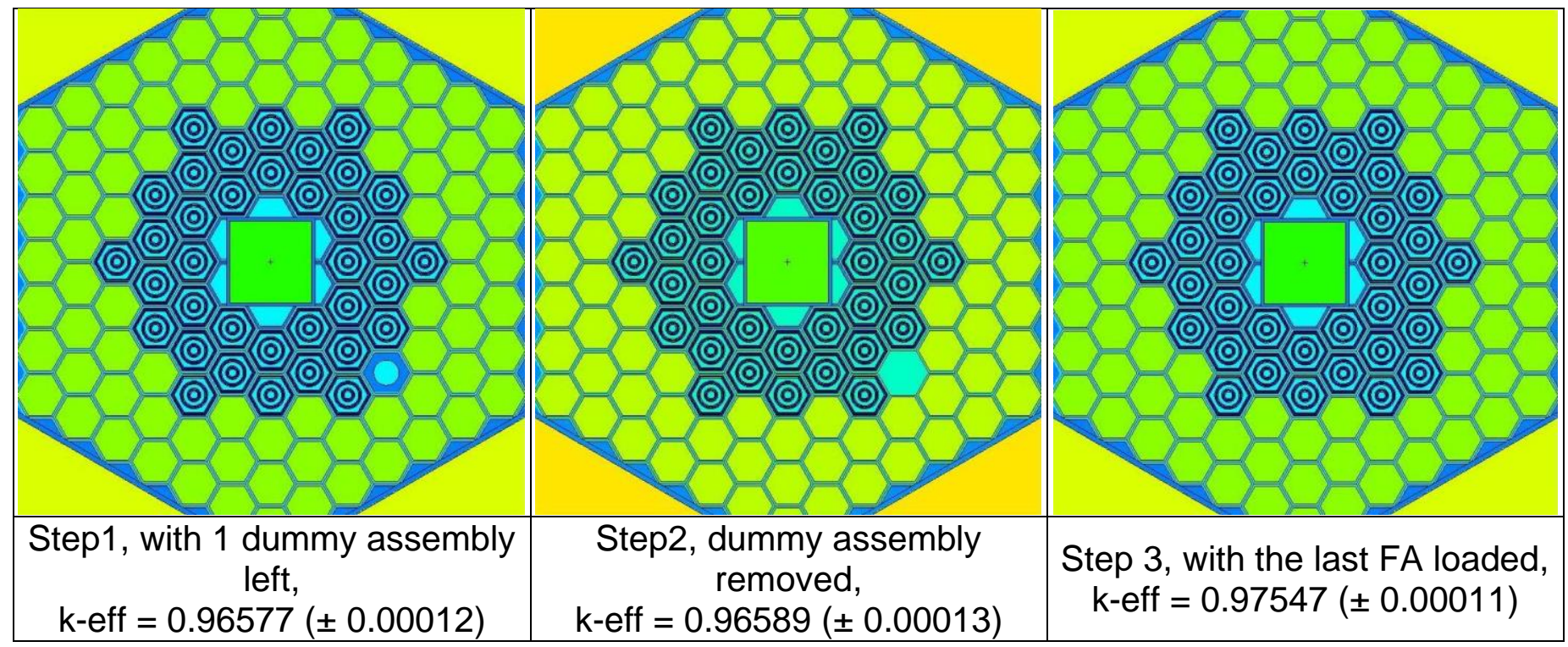

Figure 10. Subcritical assembly configurations with the uranium target of the KIPT neutron source facility during the last fuel assembly loading process

In the subcritical assembly loading process of the KIPT neutron source facility, beryllium reflector assemblies are loaded first before the dummy fuel assemblies. Eighty-two beryllium assemblies for the tungsten target case, and eighty-three beryllium assemblies for the uranium target. Criticality analyses were carried out to examine possible loading mistakes of the beryllium assemblies, some positions were loaded by dummy assemblies instead of beryllium assemblies or some positions left empty and the fuel assemblies were loaded. 
The analyses of these circumstances were also analyzed for the reference configurations for the tungsten target with 38 fuel assemblies and the uranium target with 37 fuel assemblies. These configurations and the corresponding $k_{\text {eff }}$ values are shown from

Figure 11 through 14 . The obtained results show that replacing beryllium reflector assemblies with dummy assemblies or corresponding water volume decrease the $k_{\text {eff. }}$ As expected, the reactivity worth of a beryllium assembly is larger than that of a dummy assembly or the corresponding water volume. Therefore, missing beryllium reflector assemblies will not cause safety concern, although it will decrease the neutron flux because of lower neutron multiplications.

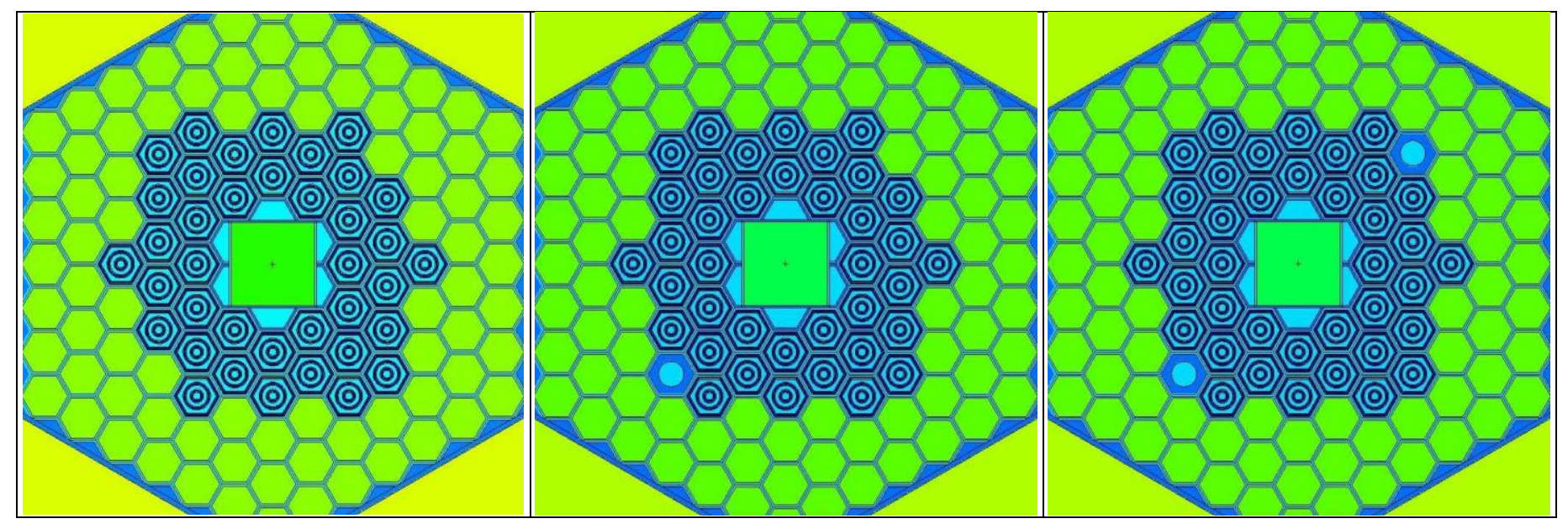

Figure 11. Subcritical assembly configurations of the KIPT neutron source with tungsten target and 38 fuel assemblies and beryllium assemblies replaced by dummy assemblies

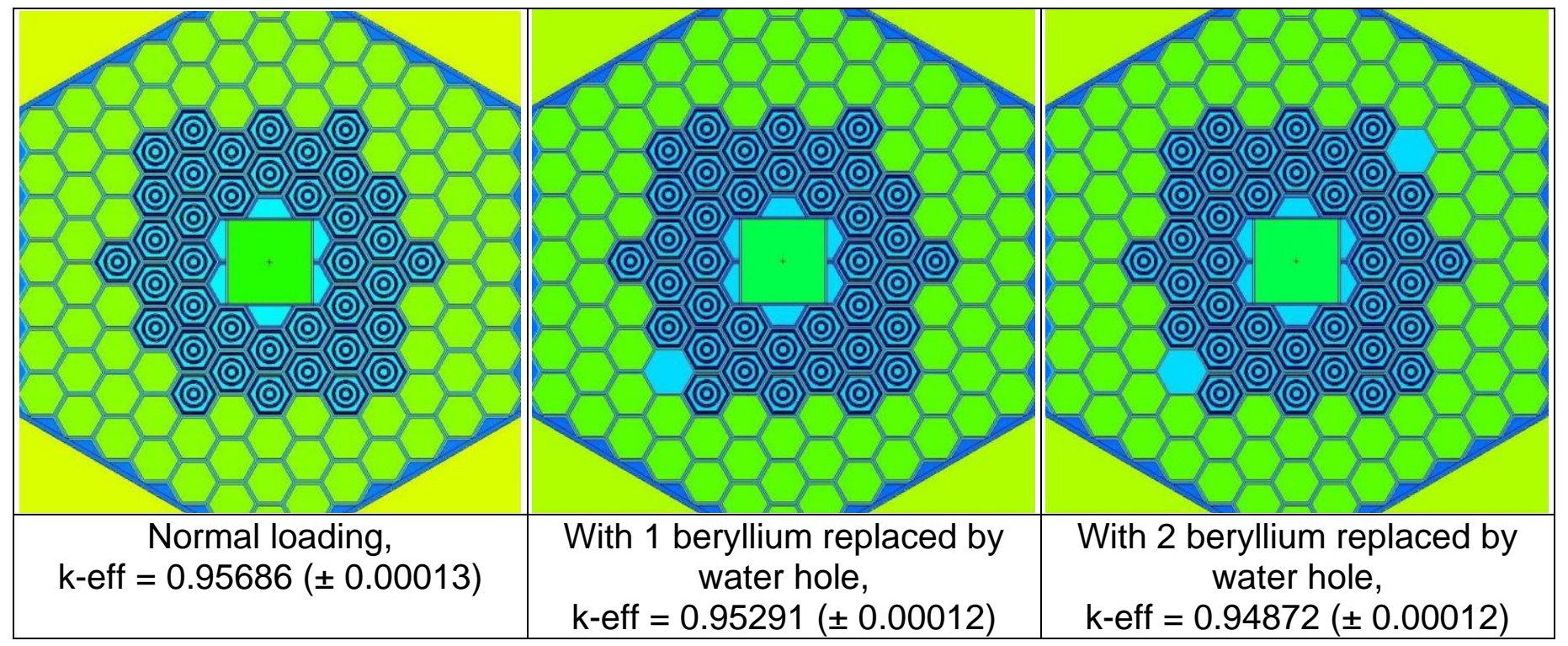

Figure 12. Subcritical assembly configurations of the KIPT neutron source with tungsten target and 38 fuel assemblies and beryllium assemblies replaced by equivalent water volumes 


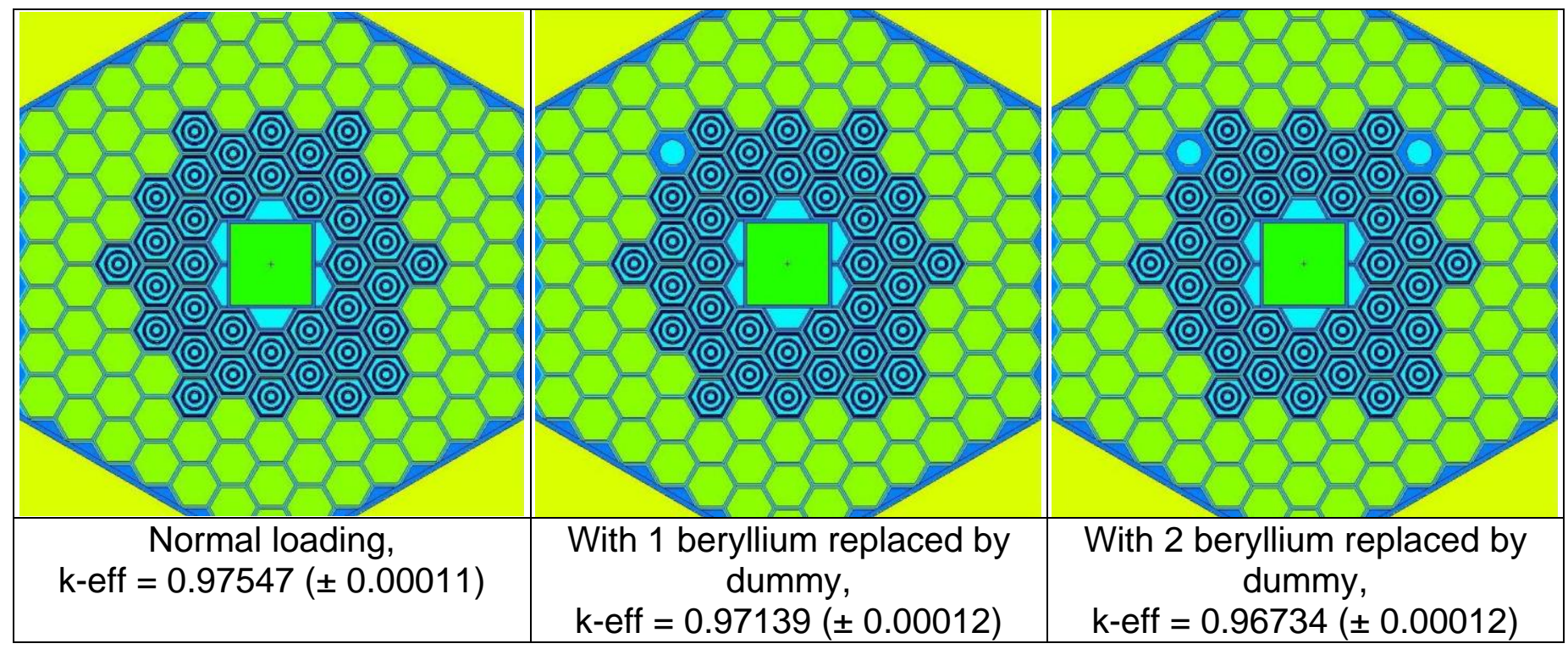

Figure 13. Subcritical assembly configurations of the KIPT neutron source with uranium target and 37 fuel assemblies and beryllium assemblies replaced by dummy assemblies

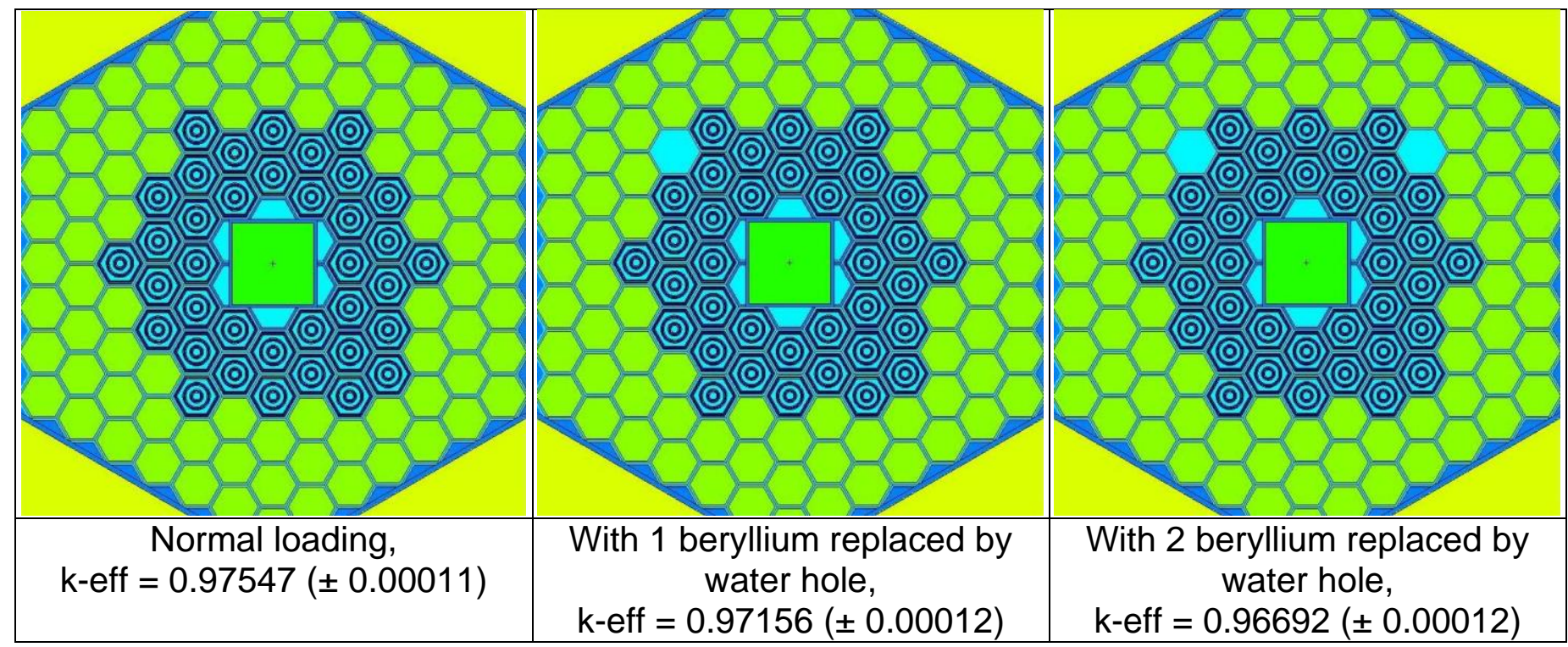

Figure 14. Subcritical assembly configurations of the KIPT neutron source with uranium target and 37 fuel assemblies and beryllium assemblies replaced by equivalent water volumes

\section{Summary and Conclusion}

Argonne National Laboratory (ANL) and the National Science Center-Kharkov Institute of Physics and Technology (NSC-KIPT) have been collaborating on developing a neutron source facility based on the use of an electron accelerator driven sub-critical system. The construction of the neutron source facility has been finished and the commission process is currently 
underway. The safety performance of the KIPT neutrons source facility were analyzed for abnormal conditions.

First, the effective neutron multiplication was analyzed as a function of the number of the loaded fuel assemblies. The reference configurations have 38 fuel assemblies with the tungsten target and 37 fuel assemblies with the uranium target. The analyses show that for both tungsten target and uranium target configurations, the reactivity of a single fuel assembly is $\sim 500 \mathrm{pcm}$. It is also shown that 47 and 42 fuel assemblies are required for tungsten and uranium configurations to reach criticality, respectively. Therefore 9 and 5 extra fuel assemblies need to be loaded to the tungsten and uranium reference configurations to reach critical condition, respectively.

The temperature reactivity feedback was analyzed as function of the temperature of the different materials for different configurations. The reactivity feedback from the temperature change of each material was analyzed separately. A minor decrease of water coolant density, due to small temperature increase results in a significant reactivity drop. If the water temperature increases from room temperature to $90^{\circ} \mathrm{C}$, before reaching the boiling point, the reactivity drop would be $\sim 800 \mathrm{pcm}$, which is more than enough to offset the reactivity gain by loading an extra fuel assembly. The fuel material temperature increase results also in significant negative reactivity feedback. When the fuel material temperature increases from room temperature to $600 \mathrm{~K}$, which is below the melting point of aluminum alloy, the reactivity drop is $\sim 500 \mathrm{pcm}$. Such impact enhances the safety performance because such reactivity feedback follows the power level change.

The analyses of transient conditions during the fuel and beryllium loading steps do not represent any safety concern because of negative reactivity feedback. Also, loading dummy assemblies instead of beryllium assemblies mistakenly results in negative reactivity feedback. So the analyses presented in this report evaluated the passive safety features of the neutron source facility during the loading process of its subcritical assembly.

\section{Acknowledgement}

This work is supported by the U.S. Department of Energy, Office of Material Management and Minimization (M3), National Nuclear Security Administration. 


\section{Reference}

[1] Y. Gohar, I. Bolshinsky, D. Naberezhnev, "Accelerator-driven sub-critical facility: conceptual design development," Nuclear Instrument and Methods Physics Research A, Vol. 562, 870-874 (2006)

[2] R. B. Pond, et al. "Neutronic performance of the WWR-M research reactor in Ukraine," Proc. 24th Intl. Meeting on Reduced Enrichment for Research and Test Reactors, San Carlos de Bariloche, Argentina, 3-8 Nov. 2002.

[3] Z. Zhong, Y. Gohar, "KIPT Neutron Source Facility Configuration using Beryllium-Graphite Reflector", ANS 2012 Summer Meeting, Chicago, IL, June 2012.

[4] Denise B. Pelowitz, ed., "MCNPX ${ }^{\mathrm{TM}}$ USER'S MANUAL," Los Alamos National Laboratory Report, LA-CP-05-0369, April 2005.

[5] M. B. Chadwick, et al.," ENDF/B-VII.0: Next Generation Evaluated Nuclear Data Library for Nuclear Science and Technology" Nuclear Data Sheet 107, pp. 2932-3061 (2006) www.elsevier.com/locate/nds 


Argonne

Nuclear Engineering Division

Argonne National Laboratory

9700 South Cass Avenue, Bldg. 208

Argonne, IL 60439

www.anl.gov 